\title{
Rare element minerals' assemblage in El Quemado pegmatites (Argentina): insights for pegmatite melt evolution from gahnite, columbite-group minerals and tourmaline chemistry and implications for minerogenesis
}

\author{
Vanina López de Azarevich ${ }^{1} \cdot$ Paolo Fulignati $^{2} \cdot$ Anna Gioncada $^{2}$ (D) $\cdot$ Miguel Azarevich $^{1}$ \\ Received: 10 August 2020 / Accepted: 26 April 2021 / Published online: 19 May 2021 \\ (C) The Author(s) 2021
}

\begin{abstract}
The pegmatite district of El Quemado (NW Pampean Ranges, NW Argentina) hosts several Ordovician pegmatite bodies of the LCT (Li, Cs, Ta) type. We present paragenetic assemblages for a set of samples from two of the El Quemado pegmatite groups, Santa Elena and Tres Tetas, and mineral chemistry analyses for gahnite, columbite-group minerals, tourmaline, micas, albite, microcline, and discuss the relation between their major element composition and the degree of evolution of pegmatite melts. The chemical composition of rare element minerals allows recognizing an evolutive trend reaching highly differentiated compositions, with complex paragenetic assemblages including Li-, Zr-, U-, Zn-, P-, Mn- and Ta-bearing minerals. The temperature of crystallization during the magmatic phase was below $400{ }^{\circ} \mathrm{C}$. Non-pervasive hydrothermal alteration, testified by a moderate presence of phyllosilicates, affected the pegmatite bodies. Chlorite geothermometry indicates that the circulation of postmagmatic hydrothermal fluids occurred at a temperature ranging between $200{ }^{\circ} \mathrm{C}$ and $250{ }^{\circ} \mathrm{C}$. The mineralogical features recognized in the El Quemado pegmatite rocks have implications for the metallogenesis of the region, suggesting that the pegmatites potentially contributed to the genesis of $\mathrm{Ta}-\mathrm{Nb}$ oxide placer mineralizations.
\end{abstract}

Keywords Rare element pegmatite $\cdot$ Columbite-group minerals $\cdot$ Gahnite $\cdot$ Tourmaline $\cdot$ El Quemado $\cdot$ Argentina

\section{Introduction}

Numerous studies demonstrated that the investigation of paragenetic assemblages, together with the chemical composition of some accessory minerals (i.e., tourmaline, $\mathrm{Nb}$ - $\mathrm{Ta}$ oxides, gahnite) represent a very useful tool for understanding the magmatic evolution of the granitic pegmatites and pegmatite melts (Tindle et al. 2002; Simmons and Webber 2008; Soares

Editorial handling: S. W. Faryad

Anna Gioncada

anna.gioncada@unipi.it

1 Centro de Estudios Geológicos Andinos, Consejo Nacional de Investigaciones Científicas y Técnicas

(CEGA-INSUGEO-CONICET), Universidad Nacional de Salta, Salta, Argentina

2 Dipartimento di Scienze della Terra di Pisa, Università di Pisa, Pisa, Italy et al. 2007; Van Hinsberg et al. 2011). In particular, the major element composition of these minerals has the potential to reveal the degree of fractionation of pegmatite melts, as well as to track their geochemical evolution up to the late magmatic stages (Batchelor and Kinnaird 1984; Breaks et al. 2005; Trumbull et al. 2009; Trumbull and Chaussidon 1999; Badanina et al. 2015). Consequently, many studies have provided models of pegmatite evolution based on the fractionation of some key elements in these accessory minerals (Černý et al. 1986; Novàk et al. 2003; Chudík et al. 2011; Van Hinsberg et al. 2011; Marks et al. 2013; Heimann et al. 2015; Feng et al. 2019; Zhou et al. 2019; Fuchsloch et al. 2019). The potential for pegmatite rocks to concentrate rare element minerals of economic interest enhances the importance of determining the chemical composition of their mineral phases and of understanding their petrogenetic history.

This research is focused on the petrographic analysis and the chemical composition of mineral species from the Santa Elena and Tres Tetas pegmatites, belonging to the Ordovician (Hongn et al. 2014) El Quemado pegmatite district (Sierra de 
Cachi, NW Argentina). The El Quemado district is the northernmost sector of the orogenic pegmatite belt that extends for $800 \mathrm{~km}$ from north to south in north-western and central Argentina, the Pampean Pegmatite Province, which provided important metal and industrial mineral resources in the past century (Galliski 2009). Previous works have described the mineral composition of pegmatites of the El Quemado district and discussed their petrogenesis (Galliski 1983a, b; Galliski and Upton 1992; Galliski et al. 1999; Galliski and Černý 2006; Sardi et al. 2017). In this paper, we present paragenetic assemblages for the Santa Elena and Tres Tetas granitic pegmatites, and chemical analysis for the primary minerals gahnite, columbite-group minerals, tourmaline, micas, albite, microcline, and for secondary chlorite. The new chemical composition data for gahnite, columbite-group minerals and tourmaline provide insights into the differentiation degree reached by these pegmatite melts and the geochemical evolution of pegmatite melt composition during fractionation. Moreover, the collected data allow inferences regarding the petrogenetic conditions during emplacement and the role of the mineralogical composition of the pegmatites for the metallogenic potential of the region. Finally, the finding and analysis of secondary chlorite allow unravelling the physical-chemical conditions occurred during a late hydrothermal stage.

\section{Geological and petrogenetic background}

The El Quemado pegmatite district is located in the Sierra de Cachi (24 ${ }^{\circ} 40^{\prime} \mathrm{S}-25^{\circ} 07^{\prime} \mathrm{S}, 6^{\circ}{ }^{\circ} 10^{\prime} \mathrm{W}-66^{\circ} 30^{\prime} \mathrm{W}$, Salta Province, NW Argentina), ca. $200 \mathrm{~km}$ west of Salta city (Fig. 1). The altitude is between 3800 and $5200 \mathrm{~m}$ above sea level.

The district is in the northwestern part of the Pampean Range structural unit, at the boundary with the Puna altiplano (Ramos 2017). The oldest rocks outcropping in the area are Neoproterozoic-Early Cambrian meta-sedimentary rocks of the Puncoviscana Formation, making transition to the cordierite schists of La Paya Formation (Hongn et al. 2014), which extend northward up to the Quilmes Ranges. These schists show evidence of a medium-high temperature, low-pressure metamorphism (Rossi de Toselli et al. 1987; Lucassen et al. 1996) and a N to NNE-trending foliation.

The Puncoviscana and La Paya Formations are intruded by the Lower Paleozoic magmatic rocks of the Cachi Formation (Galliski 1983a, b). The igneous rocks consist of two different suites: (i) gabbros, diorites, tonalites and trondhjemites, I-type; (ii) granodiorites, peraluminous granites and pegmatites, S-type. Their ages span from $477.5 \pm 3.9 \mathrm{Ma}$ for the basic rocks to $472.1 \pm 11 \mathrm{Ma}$ for granites (Hongn and Seggiaro 2001; Galliski 2007; Hongn et al. 2014; Miller et al. 2019). Basaltic bodies of $496 \pm 3 \mathrm{Ma}$ in the Río Blanco area were considered by Miller et al. (2019) as possible parents of the trondhjemitic suite, while crustal sediments' melting, without involvement of the mantle, would have produced the granitoid suite.

In the study zone, the intrusive magmatic rocks of the Cachi Formation consist of:

(i). trondhjemite plutons, composed of $\sim 60 \mathrm{vol} \%$ plagioclase and $\sim 35 \mathrm{vol} \%$ quartz; while formerly interpreted as postkinematic (Galliski 1983a; Toselli 1992), more recent works suggest syn-kinematic emplacement for these plutons, during the extensional tectonic event (Hongn et al. 2014);

(ii). pegmatites, including rare-elements pegmatites in the $\mathrm{El}$ Quemado District, forming N to NW-striking tabular bodies, showing SW-dipping and 4 to $30 \mathrm{~m}$ of thickness; the pegmatites show intra- and peri-batholitic emplacement, with sharp cutting relations.

The Santa Elena and Tres Tetas pegmatites, which are the object of this study, have been dated at $564 \pm 25 \mathrm{Ma}$ and 545 $\pm 15 \mathrm{Ma}$, respectively, based on K-Ar ages in muscovite (Galliski 1983a). Hongn et al. (2014) U-Pb ages for the trondhjemite stocks in Aguas Calientes and Tres Tetas, and for the granite La Paya of the Cachi Formation, are Tremadocian-Katian ( $\sim 85-452 \mathrm{Ma})$. We take into account the discussions in Hongn et al. (2014) and Miller et al. (2019) regarding the older ages and adopt a Lower Ordovician age for the pegmatite cortex, supported by the geological relations with the trondhjemite pluton in the Tres Tetas zone.

The El Quemado district extends over an area of $300 \mathrm{~km}^{2}$. The pegmatites have a primary mineralogical paragenesis dominated by albite, quartz, muscovite and microcline, forming megacrysts of $1-15 \mathrm{~cm}$ in size. Common accessory minerals are tourmaline, apatite, garnet and zircon. Rareelement accessory minerals are columbite-group minerals $(\mathrm{Nb}-\mathrm{Ta})$, ixiolite $(\mathrm{Ta}-\mathrm{Nb})$, bismuth minerals (native $\mathrm{Bi}$, bismutotantalite, bismuthine and bismutite), uraninite (U), beryl (Be), spodumene ( $\mathrm{Li})$, lepidolite ( $\mathrm{Li})$, elbaite ( $\mathrm{Li}$ ), petalite ( $\mathrm{Li}$, inferred from spodumene-quartz intergrowth, Galliski and Černý 2006). The paragenetic assemblage is accompanied by diverse phosphate phases such as triplite (Fe, $\mathrm{Mn})$, triphylite $(\mathrm{Fe}, \mathrm{Li})$, amblygonite-montebrasite ( $\mathrm{Li})$ (Galliski 1981, 1983b). This mineral paragenesis implies that these pegmatites belong to the LCT ( $\mathrm{Li}, \mathrm{Cs}, \mathrm{Ta}$ ) family, rare elements class (Galliski 1999). Different types and subtypes have been recognized, following the classification of Černý (1991a) and Černý and Ercit (2005): (i) beryl type, berylcolumbite-phosphate subtype; (ii) complex type, petalite subtype; (iii) complex type, spodumene subtype (Galliski 1999).

Hydrothermal alteration minerals were first reported in El Quemado District by Galliski (1983b), who identified kaolinite, montmorillonite and chlorite. Chlorite is subordinate in the 
Fig. 1 Location, schematic geological map and age of the main geological units for the El Quemado pegmatite district (NW Argentina). Geological data from this work (field surveys) and from the geological base of the Hoja Geológica Cachi-2566-III (Hongn and Seggiaro, 2001) and Hoja Geológica San Antonio de los Cobres-2566-I (Blasco et al. 1996)

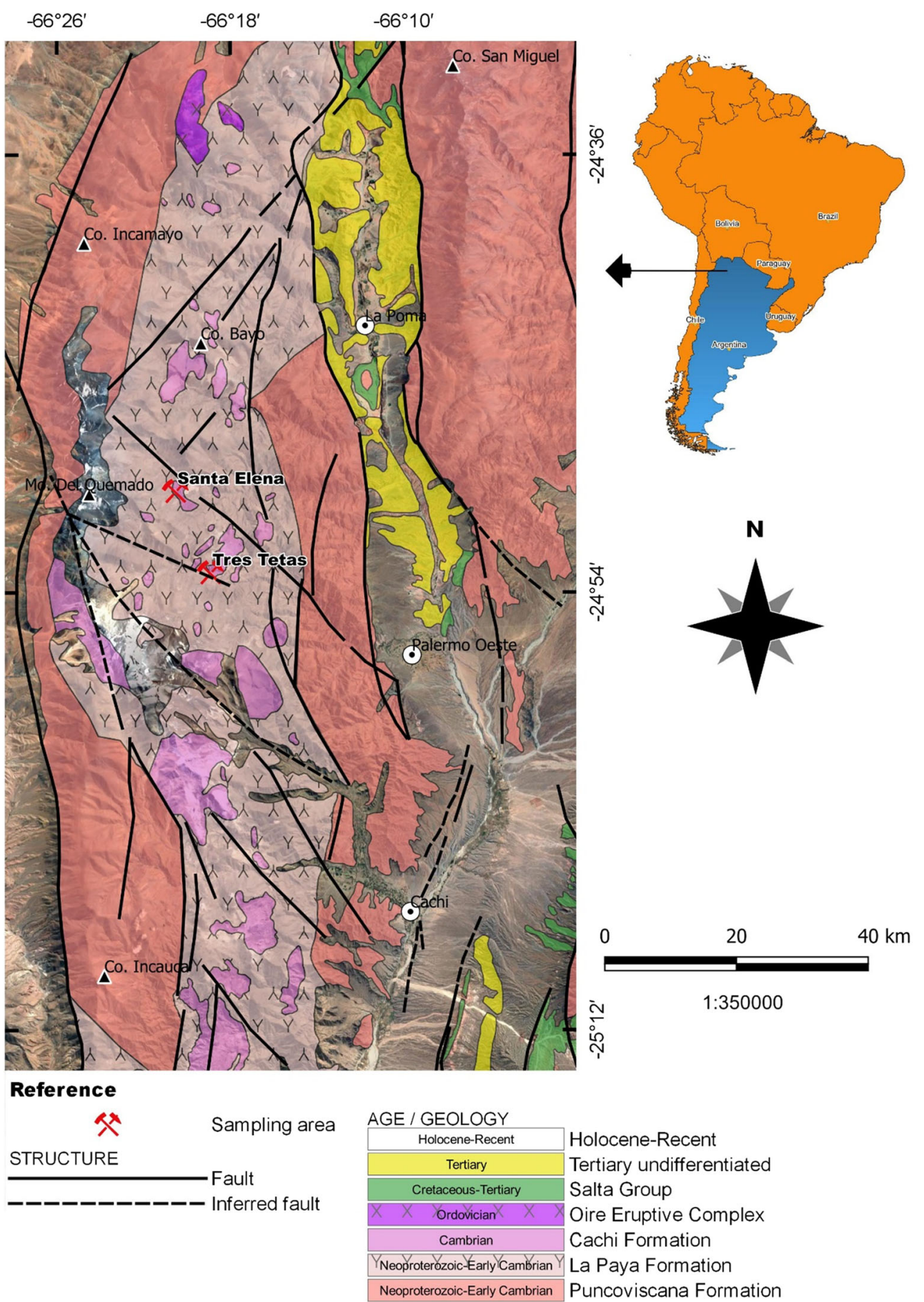

district and mentioned only in La Elvirita pegmatite $(\mathrm{N}$ of Santa Elena). Metal sulfides are associated to the final hydrothermal stages and consist of chalcopyrite $(\mathrm{Cu})$, tetrahedrite, less common molybdenite (Mo) and Bi sulfides (Galliski 1981, 1983b; Márquez-Zavalía et al. 2012), these last consisting of an assemblage dominated by $\mathrm{Bi}, \mathrm{Cu}$ and $\mathrm{S}$, with traces of $\mathrm{Pb}, \mathrm{Fe}$ and Te, reported in La Elvirita, El Peñón, El Quemado and Santa Elena pegmatites. Considering experimental data on the system $\mathrm{Cu}-\mathrm{Bi}-\mathrm{S}$ of Wang (1994),
Márquez-Zavalía et al. (2012) suggest temperatures of $300{ }^{\circ} \mathrm{C}$ to $200{ }^{\circ} \mathrm{C}$ for the stability of the assemblage emplectite + bismuthinite + native bismuth in the El Quemado pegmatite, and relate these temperatures to the late, waning hydrothermal stages.

The Li-bearing minerals, columbite-group minerals and other metalliferous accessory minerals, characteristic of these granitic pegmatites, are of notable economic and/or petrogenetic interest. The Anzotana Mining Company, operating in 
the area in 1943-1944, extracted in El Quemado Pegmatites $\sim 10$ tons of $\mathrm{Ta}-\mathrm{Nb}$ concentrates, more than 5 tons of $\mathrm{Bi}$ concentrates, with an average grade of the marketed product of $40.5 \mathrm{wt} \% \mathrm{Nb}_{2} \mathrm{O}_{5}$ and $14.5 \mathrm{wt} \% \mathrm{Ta}_{2} \mathrm{O}_{5}$, and $52.85 \mathrm{wt} \%$ Bi (Galliski 1999). The Quaternary alluvium deposits covering the area contain significant concentrations of minerals of economic interest (columbite-tantalite minerals, bismuth minerals), derived from the physical and chemical alteration (weathering) of the pegmatite bodies.

From a petrogenetic point of view, LCT pegmatites are believed to originate from extreme crystal-melt fractionation of parental granitoids, S-type and, occasionally, evolved I-type (Černý 1991b, 1998; Černý et al. 2005; London 2005; Linnen and Cuney 2005). The parental granitoids may be distal from pegmatite emplacement (Kontak 2006). In the case of study, magmatic activity during Early Paleozoic involved metaluminous trondhjemites with I-type affinity, interpreted to originate from partial melting of amphibolite mafic rocks in a continental margin arc setting (Galliski et al. 1990), and peraluminous granite apophyses with S-type affinity (Galliski 2007). The genesis of the pegmatite melts was formerly attributed to differentiation from trondhjemite magmas (Galliski 1983b). More recent works have debated this explanation based on geochemical data, and suggested models involving fractionation from the peraluminous granitoids (Galliski 2007). The emplacement of I-type and S-type granitoids and the differentiation towards highly evolved pegmatites occurred in a particularly complex geodynamic setting. Strike-slip geodynamics combined with subduction setting, as well as extensional/compressional tectonics in back-arc setting at mid-levels of the continental crust, had been proposed (Coira et al. 1999; Hongn et al. 2014).

\section{Field characteristics, internal structure, and mineralogy of El Quemado pegmatite bodies}

The El Quemado pegmatite dykes form tabular bodies with thickness from a few centimeters to over $30 \mathrm{~m}$ (Fig. 2). They have NW- and subordinately NE-striking directions, dipping $12^{\circ}$ to $90^{\circ}$ to East or West, and are displaced by NE-SW and E-W-trending faults for several meters. The host rocks consist of schists of La Paya Formation and trondhjemites of Cachi Formation.

La Paya Formation is composed by interlayered cordierite schists and subordinate quartzites. The cordierite schists host ovoidal, up to $3 \mathrm{~cm}$-long cordierite crystals accompanied by muscovite, biotite, quartz and plagioclase, oriented following the S1 metamorphic foliation, partially coinciding with $\mathrm{S} 0$ and oriented N220 $/ 50^{\circ}$ (dip direction/dip, DD/D); an axial folding S2 foliation, trending $\mathrm{N} 260^{\circ} / 40^{\circ}$, and a crenulation cleavage are also recognized.

The trondhjemitic intrusive rocks of Cachi Formation are sub-rounded bodies outcropping for up to several square kilometers, and generally form topographic highs. They have an equigranular texture consisting of euhedral, oscillatory zoned plagioclase for $50-60 \%$ by volume, and anhedral quartz, with biotite, muscovite, zircon and opaque minerals as main accessories. Occasionally, the intrusive bodies induce the development of fine grained, black hornfels, of tens of centimeters thick, at the contact with the metamorphic unit, which also are recognized as roof pendants.

In the Tres Tetas mine, the outcropping pegmatite dykes are oriented NW and subordinately NE, with steep dipping. Thickness of the dykes is $20 \mathrm{~cm}$ to $8.50 \mathrm{~m}$ and they can be followed for up to $0.5 \mathrm{~km}$ of length. Zonation within the pegmatites dykes, considering the fundamental minerals, is as follows: (i) border: $\sim 3 \mathrm{~mm}$ thick, fine-grained; (ii) wall: 5-10 cm-thick, mediumgrained, composed of up to $5 \mathrm{~cm}$-long quartz crystals, muscovite, albite, microcline; (iii) intermediate: between $10 \mathrm{~cm}$ and several meters thick, composed of milky quartz (occasionally smoky), muscovite, albite, microcline, biotite nests; (iv) core: up to $1 \mathrm{~m}$ thick, coarsegrained $(10 \mathrm{~cm}$-sized crystals), composed of quartz + albite. The lenticular morphology and oblique arrangement of cores with respect to the outer zones indicate the kinematics of deformation during emplacement of this segregated pegmatite phase. Accessory minerals are oxides (tantalite, columbite, ixiolite, gahnite, uraninite, hematite), silicates (beryl, spodumene, lepidolite, tourmaline, garnet), phosphates (amblygonitemontebrasite) and sulfides (pyrite, molybdenite) (Fig. 2 and Table 1).

In Santa Elena mine, the pegmatite dykes have a preferential NW-trending direction, thickness of $0.50 \mathrm{~m}$ to more than $30 \mathrm{~m}$, and a length of up to $0.8 \mathrm{~km}$. The host rocks are the metamorphic rocks of La Paya Formation. Border, wall and core main mineral associations are the same as those described above for Tres Tetas. In the intermediate zone, the rock-forming mineral association is quartz, plagioclase and microcline with myrmekitic rims, and accessory minerals are oxides (tantalite, columbite, gahnite, uraninite), silicates (beryl, spodumene, muscovite-lepidolite, tourmaline, garnet), phosphates (amblygonite-montebrasite, triplite) and fluorides (fluorite). Amethyst quartz is rarely present (Fig. 2 and Table 1). Some narrow dykes emplaced within the main pegmatite dyke in the exploitation area are composed of up to 80 vol\% of lepidolite + quartz. This type of subunit was recognized by Galliski (1999) and assigned to a late pegmatite replacement phase. 
Fig. 2 Examples of the pegmatite dykes in the field and of the mineral assemblage: (A) panoramic view of pegmatite dykes (arrows) emplaced in cordierite schists (CS) of the La Paya Formation and trondjemites of the Cachi Formation (T); (B) pegmatite dyke (PD) in Santa Elena zone; (C) Santa Elena principal mining labour, with on the left the fragmented blocks; (D) Santa Elena dyke association: plagioclase $(\mathrm{Pl})+$ lepidolite $(\mathrm{Lep})+$ gahnite $(\mathrm{Ghn})+$ tourmaline (Tour); (E) gahnite (Ghn) crystal from Tres Tetas pegmatite, accompanied by phosphates $(\mathrm{Ph})+$ muscovite $(\mathrm{Mu})+$ plagioclase $(\mathrm{Pl})+$ quartz $(\mathrm{Qz}) ;(\mathrm{F})$ gahnite crystal, sample Q11
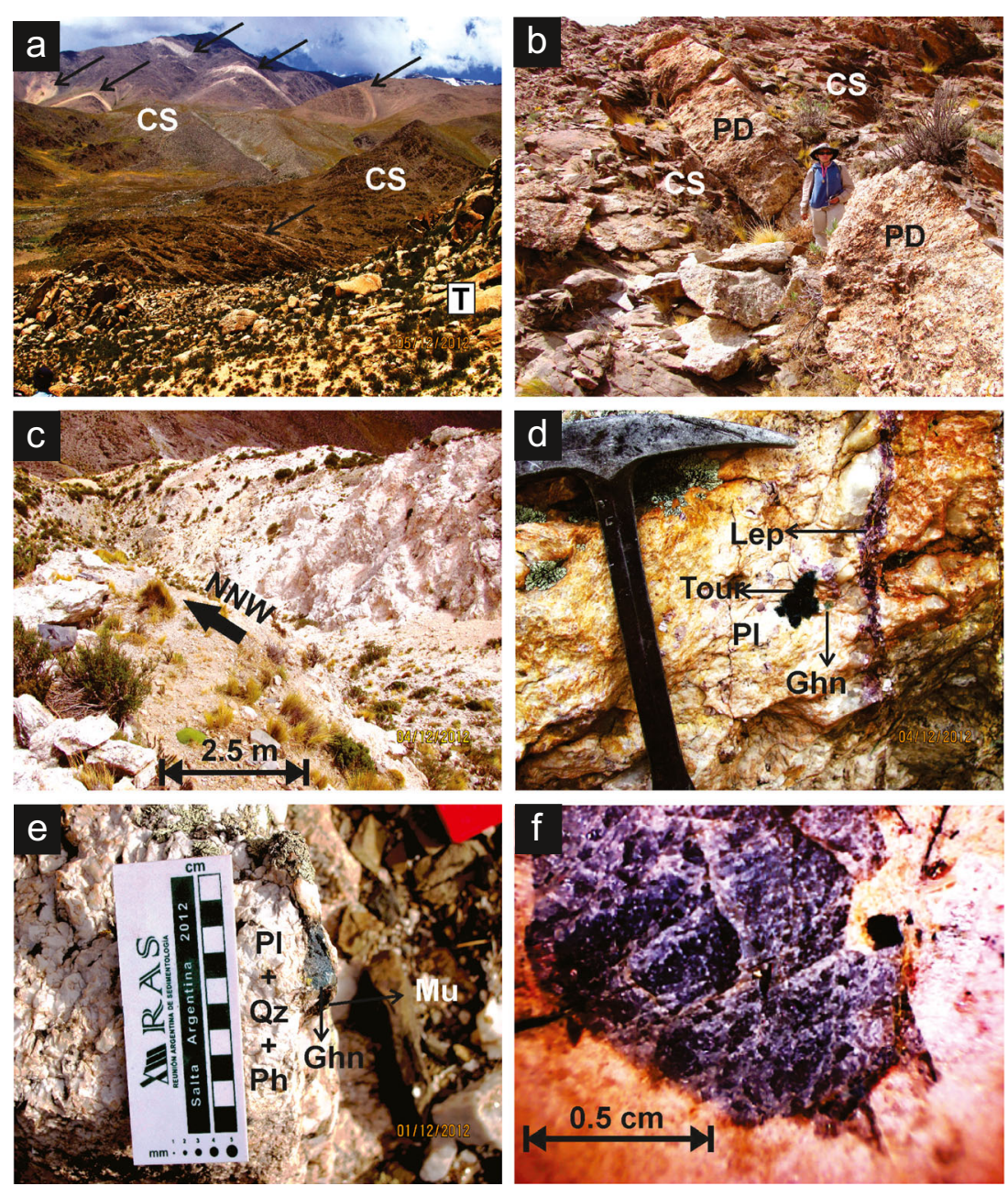

\section{Sampling and analytical methods}

\section{Sample collection and specimen preparation for optical petrography and microanalysis}

Samples were collected by the authors from the intermediate zone of the pegmatite dykes, in both Tres Tetas (samples Q12, Q13) and Santa Elena (samples Q1 to Q11 and sample Q14) mines.

Standard-sized $27 \times 47 \mathrm{~mm}$ petrographic thin sections of default $30 \mu \mathrm{m}$ nominal thickness were made for mineralogical and paragenetic analysis, while extra thick $500 \mu \mathrm{m}$ polished sections were made from mineral separates and larger specimens of gahnite and tourmaline collected in the field. Petrographic analysis was conducted using Leitz Orthoplan reflected/transmitted light microscope at the School of Geology, National University of Salta (UNSa), Argentina.

\section{Electron microscopy and in-situ mineral chemistry}

To prevent charge build-up under the impeding electron beam, polished specimen were thermally coated with conductive carbon in a Leica EM ACE600.
BSE-imaging and qualitative element analysis were conducted using a FEI Quanta 450 field-emission scanning electron microscope (FE-SEM) equipped with a Bruker-Quantax energy-dispersive spectrometer (EDS), located at the University of Pisa, Italy, operated in high vacuum $\left(<10^{-5}\right.$ Torr $)$ at $20 \mathrm{kV}$ acceleration voltage, $10 \mathrm{nA}$ beam current (on Faraday cup) and $1 \mu \mathrm{m}$ nominal diameter, keeping a constant $10 \mathrm{~mm}$ working distance.

Quantitative mineral compositions were determined on preselected spots in a JEOL JXA-8200 SuperProbe electron-probe micro-analyzer (EPMA) instrument located at the Department of Earth Sciences "Ardito Desio" of the University of Milan, Italy. The instrument is equipped with five wavelength-dispersive spectrometers (WDS) with a range of LiF, PET and TAP crystals, and one additional EDS detector. The tungsten-filament instrument was operated in high vacuum $\left(<5 \cdot 10^{-6}\right.$ Torr $), 15 \mathrm{kV}$ acceleration voltage, $5 \mathrm{nA}$ beam current, $3 \mu \mathrm{m}$ nominal beam size and $20 \mathrm{~s}$ counting time on peak and $10 \mathrm{~s}$ on background. $\mathrm{Na}$ and $\mathrm{K}$ were assigned to separate WDS spectrometers at the beginning of each analysis to minimize alkali migration. 
Table 1 Accessory minerals accompanying quartz, albite, microcline and muscovite in Santa Elena and Tres Tetas pegmatite dykes, identified by their macroscopic characteristics; X: present; -: not identified

\begin{tabular}{|c|c|c|c|c|}
\hline Group & Mineral & Characteristics & Tres Tetas & Santa Elena \\
\hline \multirow[t]{6}{*}{ Oxides } & Tantalite & Tabular, reddish-brown & $\mathrm{X}$ & $\mathrm{X}$ \\
\hline & Columbite & $\begin{array}{l}\text { Prismatic, sometimes developing chains or nests formed } \\
\text { by crystals up to } 5 \mathrm{~mm} \text {-long }\end{array}$ & $\mathrm{X}$ & $\mathrm{X}$ \\
\hline & Ixiolite & Fine, tabular, black, diamond-bright & $\mathrm{X}$ & - \\
\hline & Gahnite & $\begin{array}{l}\text { Sub-euhedral to euhedral, dark blue to turquoise coloured, } \\
\text { up to several cm- crystals }\end{array}$ & $\mathrm{X}$ & $\mathrm{X}$ \\
\hline & Uraninite & Black, short tabular; green to yellow colours & $\mathrm{X}$ & $\mathrm{X}$ \\
\hline & Hematite & Globular aggregates or euhedral crystals formed after pyrite & $\mathrm{X}$ & - \\
\hline \multirow[t]{6}{*}{ Silicates } & Beryl & Fibrous, apple green & $\mathrm{X}$ & $\mathrm{X}$ \\
\hline & Spodumene & White to light grey & $\mathrm{X}$ & $\mathrm{X}$ \\
\hline & Lepidolite & Pink to violet, associated to muscovite and subordinate garnet & $\mathrm{X}$ & $\mathrm{X}$ \\
\hline & Garnet & $\begin{array}{l}\text { Sub-euhedral, up to } 3 \mathrm{~mm} \text { diameter, reddish-brown, } \\
\text { sometimes developing aggregates }\end{array}$ & $\mathrm{X}$ & $\mathrm{X}$ \\
\hline & Schorl & Prismatic, black & $\mathrm{X}$ & $\mathrm{X}$ \\
\hline & Elbaite & Prismatic, blue violet & - & $\mathrm{X}$ \\
\hline \multirow[t]{2}{*}{ Phosphates } & Amblygonite-Montebrasite & White, prismatic & $\mathrm{X}$ & $\mathrm{X}$ \\
\hline & Triplite & Reddish-brown, vitreous & - & $\mathrm{X}$ \\
\hline Fluorides & Fluorite & Violet, sometimes associated to lepidolite & - & $\mathrm{X}$ \\
\hline \multirow[t]{2}{*}{ Sulphides } & Molybdenite & Fine-grained, blueish grey & $\mathrm{X}$ & - \\
\hline & Pyrite & Pseudomorphically replaced by hematite & $\mathrm{X}$ & - \\
\hline
\end{tabular}

The instrument was internally calibrated using mineral standards and metals of natural and synthetic origin, notably: grossular $(\mathrm{Si} \mathrm{K} \alpha, \mathrm{Ca} \mathrm{K} \alpha$, $\mathrm{Al} \mathrm{K} \alpha)$, omphacite $(\mathrm{Na} \mathrm{K} \alpha)$, forsterite $(\mathrm{Mg} K \alpha)$, fayalite $(\mathrm{Fe} K \alpha)$, ilmenite (Ti $\mathrm{K} \alpha)$, orthoclase $(\mathrm{K} \mathrm{K} \alpha)$, rhodonite $(\mathrm{Mn} \mathrm{K} \alpha)$, pure metals $\mathrm{Cr}(\mathrm{Cr} \mathrm{K} \alpha), \mathrm{Nb}$ $(\mathrm{Nb} \mathrm{L} \alpha), \mathrm{Ta}(\mathrm{Ta} \mathrm{L} \alpha), \mathrm{Zn}(\mathrm{Zn} \mathrm{K} \alpha)$, and $\mathrm{PbO}(\mathrm{Pb} \mathrm{M} \alpha), \mathrm{UO}_{2}(\mathrm{U}$ $\mathrm{M} \alpha$ ). Raw element data were ZAF-corrected using phi-rho-Z analysis program, and corrected element contents were converted to oxide contents in weight percent (wt $\%$ ) assuming stoichiometry. $\mathrm{FeO}^{\mathrm{T}}$ represents total iron (oxide) content. Ultralight (element) species $\mathrm{B}, \mathrm{Li}$, and $\mathrm{H}_{2} \mathrm{O}$ were not measured but instead calculated by stoichiometry, where applicable.

Main element oxide contents were recast into numbers of cations in atoms per formula unit (apfu) following the general guidelines in the appendices to Deer et al. (1983), applying IMA-approved classification and nomenclature as available (e.g., Bayliss 1975, Rieder et al. 1998, Henry et al. 2011).

\section{Mineral identification by X-ray powder diffraction (XRPD)}

For identification purposes, selected mineral fragments were pulverized in an agate mortar and pestle, until a smooth paste without granularity when rubbed between fingertips was obtained. The powders were mounted on a zero-background glass plate lightly greased with silicone. X-ray diffractograms were recorded in a Rigaku D/MAX IIIC diffractometer located at the Department of Geology of the National University of the South, Argentina. The X-ray tube was operated at $35 \mathrm{kV}$ and $15 \mathrm{~mA}$ cathode current producing bulk $\mathrm{CuK} \alpha$ radiation at $\lambda=1.54059 \AA$, whereas $\mathrm{CuK} \beta$ was removed by a graphite monochromator. Diffractograms were recorded from 3 to $60{ }^{\circ} 2 \theta$ in $0.04{ }^{\circ} 2 \theta$ increments and $1 \mathrm{~s}$ counting time per step. Peaks were indexed and mineral species were identified using the JADE software and database.

\section{Results}

\section{Petrography and mineral chemistry}

The EPMA chemical composition and the textural relationships of the minerals tourmaline, gahnite, columbite-tantalite, feldspars and mica (primary) and chlorite (secondary) of El Quemado pegmatites are presented here below (see Table 2 for the full list of the mineral phases identified by petrographic and/or SEM-EDS or XRD). Other minerals identified with optical petrography and with SEM-EDS analysis are also described for textural relationships and semiquantitative elemental composition. Examples of textural relationships are shown in Figs. 3 and 4. Mineral abbreviations follow Whitney and Evans (2010).

Tourmalines In the studied pegmatites, tourmaline occurs as prismatic, blue to dark blue and black crystals, sometimes 
forming clusters of radiated aggregates, ranging in size from 0.5 to $5 \mathrm{~cm}$. The crystals exhibit pleochroism of variable intensity, generally diminishing or absent towards the rims. From the paragenetic point of view, in both Tres Tetas and Santa Elena samples, tourmaline is found in association with the fundamental minerals quartz, albite, muscovite-lepidolite and occasionally $\mathrm{Al}$ - and Ca-phosphates, and presents apatite inclusions (Fig. 3a, d).

The structural formulae of the analysed tourmalines were calculated assuming the general formula with 15 cations in the octahedral and tetrahedral $(\mathrm{Y}+\mathrm{Z}+\mathrm{T})$ sites and 31 anions, as proposed by Henry et al. (2011). $\mathrm{B}_{2} \mathrm{O}_{3}, \mathrm{H}_{2} \mathrm{O}$ and $\mathrm{Li}_{2} \mathrm{O}$ are calculated by stoichiometry for $\mathrm{OH}+\mathrm{F}=4$ apfu, $\mathrm{B}=3$ apfu and $\mathrm{Li}=15-(\mathrm{T}+\mathrm{Y}+\mathrm{Z})$ and normalized to 31 anions. Tourmaline compositions are given in Table 3. Tourmalines of Santa Elena and Tres Tetas pegmatites belong to the alkali group (Fig. 5a) following the nomenclature of Henry et al. (2011). All the tourmalines are Al-rich compared to the ideal schorl-dravite formulae, with total $\mathrm{Al}$ contents between 6.5 and 8.0 apfu and large alkali deficiencies (12\%-50\% X-site vacancies). The recalculated analyses show that, except for those in sample Q3, all tourmalines are Li-rich (Fig. 5b, Table 3), particularly those found in samples Q4, Q6 and Q7 (Santa Elena) and Q12 (Tres Tetas). No noticeable core-rim Li zoning has been observed. According to the classification of Henry et al. (2011), Q3 sample tourmalines are classified as schorl, with the exception of one analysis that falls in the foitite compositional field; all the other tourmalines are elbaites, as also shown in Fig. 5 b.

Columbite-group minerals Columbite-group minerals (CGM) were only analysed in the Santa Elena pegmatites. These oxides occur in close association with gahnite, Al-phosphates and quartz (quartz forms throughout the entire crystallization of the pegmatitic melt), isolated or in clusters of 2-3 individuals (Fig. 4a-c) and are generally unzoned but, in some examples, strongly zoned in the $\mathrm{Nb} / \mathrm{Ta}$ ratio (Fig. $4 \mathrm{~d}$ ). The chemical composition of CGM is shown in Table 4. The recalculated formula is close to the ideal 1:2 stoichiometry (Table 4). In the columbite-tantalite quadrilateral proposed

Table 2 Minerals identified by petrographic and/or SEM-EDS analysis of thin sections and XRD; X: present; -: not identified

\begin{tabular}{|c|c|c|c|c|c|c|c|c|c|c|c|c|c|c|}
\hline & & \multicolumn{11}{|c|}{ SANTA ELENA } & \multicolumn{2}{|c|}{ TRES TETAS } \\
\hline \multicolumn{2}{|l|}{ Sample } & Q1 & Q2 & Q3 & Q4 & Q6 & Q7 & Q8 & Q9 & Q10 & Q11 & Q14 & Q12 & Q13 \\
\hline \multicolumn{15}{|c|}{ Fundamental and accessory primary minerals } \\
\hline \multirow[t]{9}{*}{ Silicates } & Quartz & - & $\mathrm{X}$ & $\mathrm{X}$ & - & - & $\mathrm{X}$ & - & $\mathrm{X}$ & $\mathrm{X}$ & $\mathrm{X}$ & $\mathrm{X}$ & $\mathrm{X}$ & - \\
\hline & Albite & $\mathrm{X}$ & - & $\mathrm{X}$ & $\mathrm{X}$ & $\mathrm{X}$ & $\mathrm{X}$ & - & - & - & $\mathrm{X}$ & $\mathrm{X}$ & $\mathrm{X}$ & $\mathrm{X}$ \\
\hline & Microcline & - & - & $\mathrm{X}$ & - & $\mathrm{X}$ & - & - & - & - & - & - & - & - \\
\hline & Tourmaline & - & - & $\mathrm{X}$ & $\mathrm{X}$ & $\mathrm{X}$ & $\mathrm{X}$ & $\mathrm{X}$ & - & - & - & $\mathrm{X}$ & $\mathrm{X}$ & - \\
\hline & Micas & - & $\mathrm{X}$ & $\mathrm{X}$ & $\mathrm{X}$ & $X$ & - & $\mathrm{X}$ & $\mathrm{X}$ & - & $\mathrm{X}$ & $X$ & $\mathrm{X}$ & - \\
\hline & Spodumene & $\mathrm{X}$ & - & - & $\mathrm{X}$ & $X$ & - & - & $\mathrm{X}$ & - & $\mathrm{X}$ & $\mathrm{X}$ & - & - \\
\hline & Beryl & - & - & - & - & - & - & - & - & - & - & - & $\mathrm{X}$ & - \\
\hline & Zircon & - & - & $\mathrm{X}$ & - & - & $\mathrm{X}$ & - & - & - & $\mathrm{X}$ & - & - & - \\
\hline & Cs-silicate & - & - & - & - & - & - & - & - & - & - & - & $\mathrm{X}$ & - \\
\hline \multirow[t]{4}{*}{ Phosphates } & Apatite $(\mathrm{Mn})^{(1)}$ & - & - & $\mathrm{X}$ & $\mathrm{X}$ & $\mathrm{X}$ & $\mathrm{X}$ & - & - & - & - & - & $\mathrm{X}$ & - \\
\hline & Al-phosphate (amblygonite-montebrasite) & $\mathrm{X}$ & - & - & $\mathrm{X}$ & - & $\mathrm{X}$ & $\mathrm{X}$ & - & $\mathrm{X}$ & $\mathrm{X}$ & $\mathrm{X}$ & - & $\mathrm{X}$ \\
\hline & Mn-Fe phosphate (triplite group) & - & - & - & - & - & $\mathrm{X}$ & - & - & - & - & - & $\mathrm{X}$ & $\mathrm{X}$ \\
\hline & Xenotime & - & - & - & - & - & - & - & - & - & $\mathrm{X}$ & - & - & - \\
\hline \multirow[t]{4}{*}{ Oxides } & Columbite-tantalite & - & - & $\mathrm{X}$ & $\mathrm{X}$ & - & $\mathrm{X}$ & - & - & - & $\mathrm{X}$ & - & - & - \\
\hline & Gahnite & - & - & - & - & - & $\mathrm{X}$ & $\mathrm{X}$ & - & - & $\mathrm{X}$ & - & - & - \\
\hline & W-oxide & - & - & - & - & - & - & - & - & - & - & - & - & $\mathrm{X}$ \\
\hline & Uraninite & - & - & - & - & - & $\mathrm{X}$ & - & - & - & $\mathrm{X}$ & - & - & - \\
\hline \multirow[t]{2}{*}{ Sulphides } & Pyrite & - & - & - & - & - & - & - & - & - & - & - & - & $\mathrm{X}$ \\
\hline & Sphalerite & - & - & - & - & - & - & - & - & - & - & - & $\mathrm{X}$ & - \\
\hline \multicolumn{15}{|c|}{$\underline{\text { Secondary minerals }}$} \\
\hline \multicolumn{2}{|c|}{ Phosphates (U) ${ }^{(2)}$} & - & - & - & - & - & - & - & - & - & $\mathrm{X}$ & - & - & - \\
\hline \multicolumn{2}{|l|}{ Chlorite } & - & - & - & - & - & $\mathrm{X}$ & - & - & - & - & - & - & - \\
\hline \multicolumn{2}{|l|}{ Baryte } & - & - & $X$ & - & - & - & - & - & - & - & - & - & - \\
\hline \multicolumn{2}{|l|}{ Clays } & - & - & - & - & - & - & - & - & - & $X$ & - & - & - \\
\hline
\end{tabular}

${ }^{(1)}$ Apatite (Ca-phosphate) containing Mn, identified by EDS spectrum; ${ }^{(2)}$ Phosphate of uranium, identified by EDS spectra, probably autunite group 
Fig. 3 SEM-BSE images showing the main minerals of El Quemado pegmatites: (a) albite+ microcline+Al-phosphate, Q6 sample; (b) albite+microcline+ mica, Q7 sample; (c) mica+quartz with phosphate veinlets, Q12 sample; (d) zoned tourmaline+ quartz+mica, Q6 sample. Qtz: quartz; Tur: tourmaline; Ab: albite; Mc: microcline
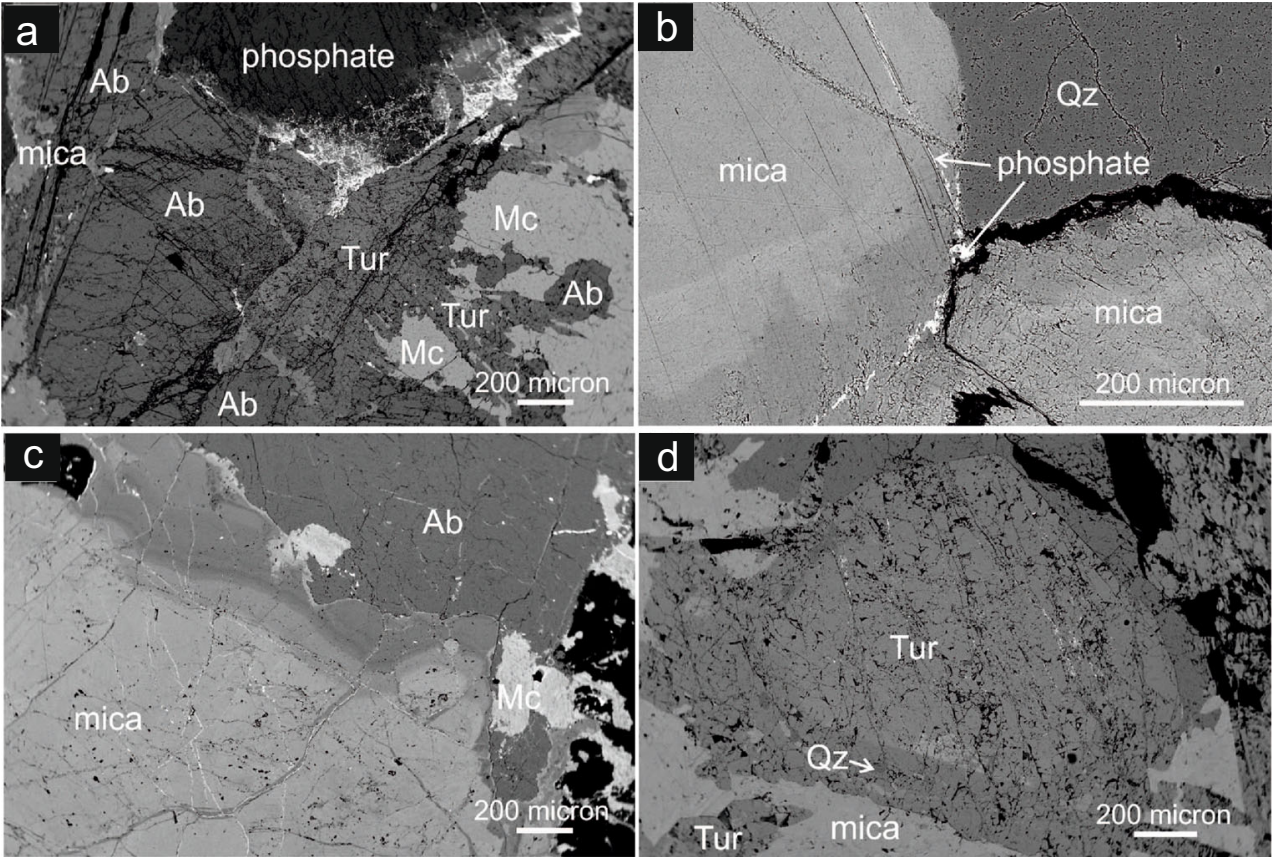

by Černý (1989), the analyses plot largely within the columbite field $(\mathrm{Ta} /(\mathrm{Ta}+\mathrm{Nb})<0.5)$, with values of the $\mathrm{Mn} /(\mathrm{Mn}+$ $\mathrm{Fe}$ ) ratio that span between ca. 0.40 and 0.95 (Fig. 6). The data plot in the fields of columbite-(Fe), columbite-(Mn) and, in two cases, tantalite-(Mn), and show a positive correlation between $\mathrm{Ta} /(\mathrm{Ta}+\mathrm{Nb})$ and $\mathrm{Mn} /(\mathrm{Mn}+\mathrm{Fe})$.

Gahnite Gahnite was analysed in two samples of the Santa Elena pegmatites. It shows idiomorphic crystals up to centimetric in size, in association with quartz, $\mathrm{Nb}$ - $\mathrm{Ta}$ oxides and phosphates (Fig. 4a, b). Some crystals are cut by fine veinlets of unidentified late silicates.

The chemical composition of gahnite is reported in Table 5 and shows very high $\mathrm{Zn}$ content ( $>40 \mathrm{wt} \%$; up to $100 \% \mathrm{Ghn}$ ) and low Fe content $(<1.5 \mathrm{wt} \%$, or $4.3 \% \mathrm{Hc})$ (Fig. 7$)$. The contents of $\mathrm{Mg}, \mathrm{Mn}$ and $\mathrm{Cr}$ elements are very low (< $0.13 \mathrm{wt} \%$ ), consequently spinel (Spl) and galaxite (Glx) components are negligible. A compositional profile across a large gahnite crystal indicates that no significant compositional zoning affects gahnite of Santa Elena pegmatites (Fig. 8).

Feldspars Albite and microcline coexist as large crystals or crystal aggregates in both the Tres Tetas and Santa Elena pegmatites, together with quartz, mica, tourmaline and phosphate (Fig. 3a, c). Albite is more abundant than microcline and mainly occurs in radiated masses of platy crystals, corresponding to the platy variety called cleavelandite. Subordinately, albite occurs in aggregates showing a granular texture. Albite shows nearly end-member composition, with at most $1.1 \mathrm{~mol} \%$ Or and $0.4 \mathrm{~mol} \%$ An. Microcline can be easily recognized by the coarse crosshatched multiple twinning ("tartan twinning"), characteristic of low-T alkali-feldspar. Microcline contains up to $3.2 \mathrm{~mol} \% \mathrm{Ab}$ and negligible $\mathrm{An}$ (Table 6). Perthitic texture is not common.

The textural relationships suggest the contemporaneous crystallization of the two feldspars. This feature is typical of "subsolvus" granites and agrees with the high $\mathrm{P}_{\mathrm{H} 2 \mathrm{O}}$ conditions during the crystallization of the pegmatite melt.

Mica-group minerals In the studied pegmatites, mica occurs as grey, pink to violet crystals. The composition of mica was analysed by EPMA in the Santa Elena samples (Fig. 3a-d). The results display a spectrum from nearly stoichiometric muscovite, with total filling of interlayer sites, in sample Q6, to mica with $\mathrm{Na}+\mathrm{K}+\mathrm{Ca}$ as low as 1.28 (calculated on the basis of 22 anions), in sample Q11. The X-site deficiency can be explained by the presence of elements that are not analysed, such as $\mathrm{Cs}$ and $\mathrm{Rb}$. Lower $\mathrm{Al}(<26 \mathrm{wt} \%$ $\mathrm{Al}_{2} \mathrm{O}_{3}$ ) and higher $\mathrm{Fe}$ distinguish the mica analysed in sample Q7 (Table 7). When plotted in the ternary diagram Al$\mathrm{R}^{2+}$-Si (Fig. 9), the composition of the mica minerals ranges from muscovite (samples Q6 and Q11) to the field of the trilithionite-polylithionite series (sample Q7 and, in part, Q11), indicating the presence of Li-mica (intermediate between muscovite and lepidolite). These results are in agreement with those of Galliski et al. (1999), reporting chemical analyses of Li-mica in Santa Elena pegmatites. Lithium was not determined by EPMA; an estimation of Li has been, however, carried out according to Tischendorf et al. $(1997,2004)$ only in the micas with intermediate composition between muscovite and lepidolite in sample Q7, which approach the required range of validity (Table 7). 
Fig. 4 SEM-BSE images showing accessory mineral associations in the El Quemado pegmatites. (a) $\mathrm{qtz}+\mathrm{ghn}+\mathrm{Nb}$ Ta-oxides, Q11 sample; (b) detail of (a) showing phyllosilicates and phosphates with the oxides; (c) Al-phosphate crystal with $\mathrm{Nb}-\mathrm{Ta}$ oxides and quartz, cut by veinlets of secondary phosphates, Q11 sample; (d) zoned columbitetantalite and zircon, Q3 sample; $(\mathrm{e}, \mathrm{f})$ zircon $(\mathrm{Zrn})$ and xenotime (Xtm) with inclusions, with the brilliant ones being uraninite (Urn) and others being a P-bearing unidentified mineral, sample Q11; (g, h) Fe-chlorite rosettes, sample Q7
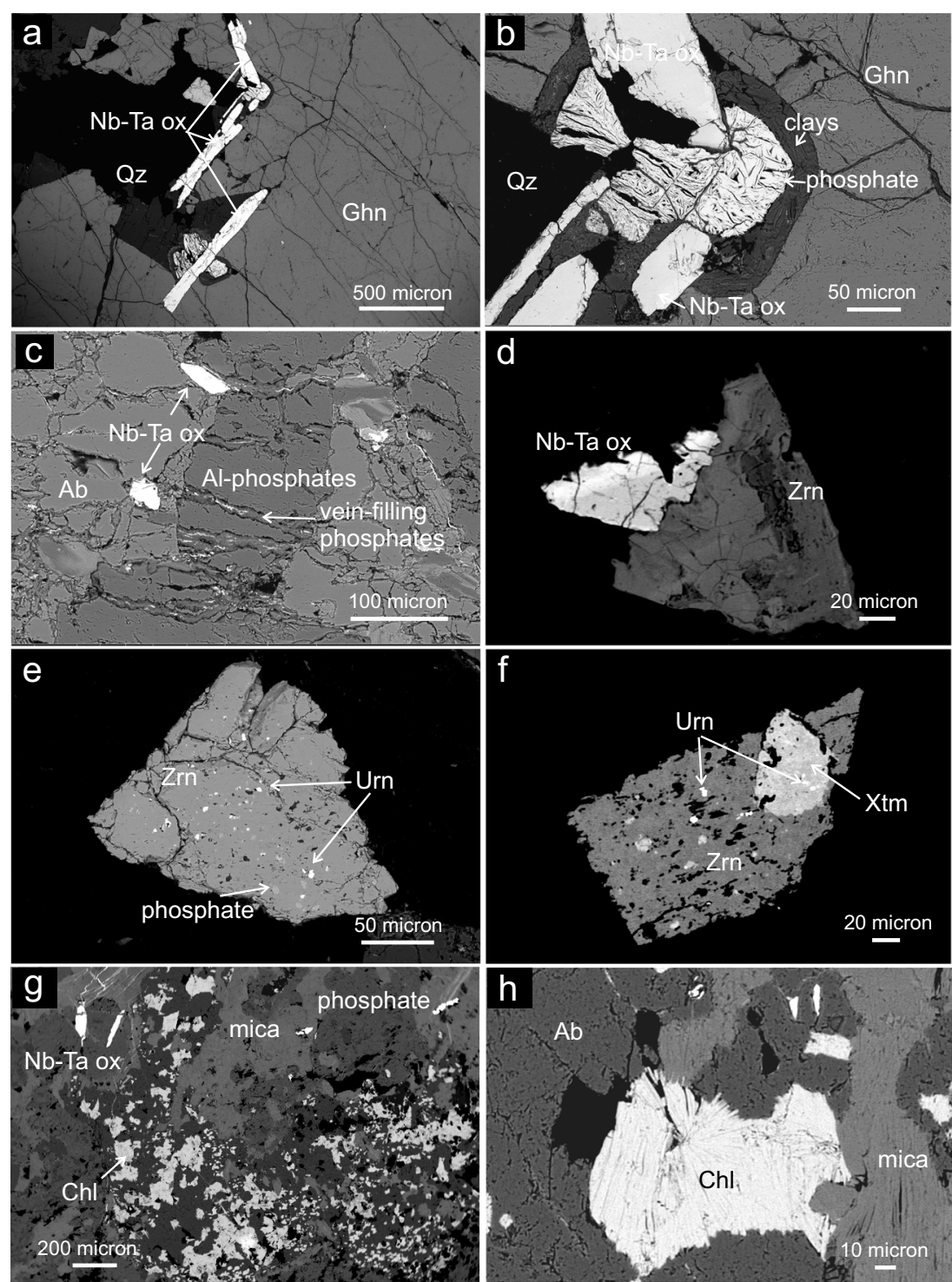

Chlorite An Fe-rich chlorite (chamosite, Table 8) occurs as densely packed rosette-shaped aggregates in some samples of Santa Elena pegmatite (Fig. 4g, h). The analysed chlorites are trioctahedral in nature, characterized by a nearly full octahedral occupancy. The number of vacant octahedral sites per twelve positions is $<0.5$. The $\mathrm{Na}+\mathrm{Ca}+\mathrm{K}$ sum is always $<0.08$ (formula based on 28 oxygens). These characteristics indicate that these chlorites are free of smectite interstratifications or corrensite packets in their structure (Martinez-Serrano and Dubois 1998 and reference therein).

Other minerals Zircon is common in both Santa Elena and Tres Tetas pegmatites in subhedral to euhedral grains that, in some cases, exhibit compositional zoning (Fig. 4d). The zircon crystals constantly host, in the core or in the entire crystal, numerous minute inclusions consisting of uraninite and other minor non-identified phases, in some cases bearing $\mathrm{P}$ and $\mathrm{U}$
(Fig. 7e, f). Xenotime with uraninite inclusions has been found associated with zircon (Fig. 4f).

Phosphate minerals are rather common in the Santa Elena and Tres Tetas samples (Figs. 3 and 4). Their EDS spectra and composition show the presence of different phosphate mineral groups. Three main phosphate groups can be recognized. The most common phosphates occur as coarse crystals in association with quartz, albite, mica and spodumene (identified by XRD) and are Al-rich with an evident F peak in the EDS spectrum, suggesting a correspondence with Al-phosphates with light elements (Li, F, OH-group). These minerals belong to the amblygonite-montebrasite group as indicated by XRD data. The second phosphate group is often in association with tourmaline and feldspars and consists of Mn-bearing Ca-phosphates (apatite group). Thirdly, Li-Fe and Mn-F phosphates of the triplite and triphylite groups are also common both in the Santa Elena and the Tres Tetas pegmatites. The phosphates of 
Table 3 Selected microprobe chemical analyses (wt \%) and compositional formulae (see text for formula calculation) of tourmaline in the El Quemado pegmatites; $\mathrm{FeO}^{\mathrm{T}}$ : all $\mathrm{Fe}$ as $\mathrm{FeO}$; bdl: below detection limit. *: calculated by stoichiometry following Henry et al. (2011). Rim and core analysis are specified for crystals zoned in BSE images

\begin{tabular}{|c|c|c|c|c|c|c|c|c|c|c|}
\hline Sample & Q3 & Q4 & Q4 & Q4 & Q6 & Q7 & Q7 & Q7 & Q12 & Q12 \\
\hline & core & & core & rim & & & & & & \\
\hline $\mathrm{SiO}_{2}$ & 37.06 & 36.87 & 37.89 & 37.80 & 36.47 & 36.69 & 37.48 & 37.46 & 38.49 & 38.66 \\
\hline $\mathrm{TiO}_{2}$ & 0.04 & 0.05 & 0.04 & 0.04 & 0.01 & bdl & 0.04 & 0.07 & bdl & 0.02 \\
\hline $\mathrm{Al}_{2} \mathrm{O}_{3}$ & 34.89 & 36.91 & 39.52 & 37.83 & 36.13 & 36.32 & 38.85 & 37.78 & 38.17 & 37.70 \\
\hline $\mathrm{Cr}_{2} \mathrm{O}_{3}$ & 0.02 & bdl & bdl & 0.03 & bdl & bdl & bdl & bdl & bdl & bdl \\
\hline $\mathrm{FeO}^{\mathrm{T}}$ & 9.73 & 7.19 & 1.77 & 3.48 & 10.34 & 8.59 & 3.95 & 5.35 & 2.46 & 1.29 \\
\hline $\mathrm{MnO}$ & 0.17 & 0.48 & 1.82 & 1.45 & 0.39 & 0.30 & 0.62 & 0.73 & 2.04 & 2.68 \\
\hline $\mathrm{MgO}$ & 3.70 & 0.02 & bdl & 0.02 & 0.12 & 0.23 & 0.04 & 0.13 & 0.01 & bdl \\
\hline $\mathrm{CaO}$ & 0.09 & 0.08 & 0.15 & 0.16 & 0.04 & 0.03 & 0.18 & 0.15 & 0.20 & 0.30 \\
\hline $\mathrm{Na}_{2} \mathrm{O}$ & 1.52 & 2.55 & 2.26 & 2.43 & 1.72 & 2.32 & 2.53 & 2.46 & 2.49 & 2.49 \\
\hline $\mathrm{K}_{2} \mathrm{O}$ & 0.03 & 0.02 & 0.03 & 0.01 & 0.01 & 0.02 & 0.01 & 0.04 & bdl & 0.03 \\
\hline $\mathrm{B}_{2} \mathrm{O}_{3} *$ & 10.73 & 10.51 & 10.72 & 10.59 & 10.48 & 10.48 & 10.66 & 10.62 & 10.70 & 10.65 \\
\hline $\mathrm{Li}_{2} \mathrm{O}^{*}$ & 0.21 & 1.36 & 1.79 & 1.84 & 0.79 & 1.12 & 1.72 & 1.56 & 2.02 & 2.24 \\
\hline $\mathrm{H}_{2} \mathrm{O}^{*}$ & 3.70 & 3.62 & 3.70 & 3.65 & 3.62 & 3.61 & 3.68 & 3.66 & 3.69 & 3.67 \\
\hline Total & 101.94 & 99.93 & 100.03 & 99.68 & 100.27 & 99.93 & 100.09 & 100.31 & 100.67 & 100.16 \\
\hline \multicolumn{11}{|l|}{$T:$} \\
\hline $\mathrm{Si}$ & 5.99 & 5.99 & 6.00 & 6.05 & 5.98 & 6.00 & 5.97 & 6.01 & 6.09 & 6.13 \\
\hline $\mathrm{Al}$ & 0.01 & 0.01 & 0.00 & 0.00 & 0.02 & 0.00 & 0.03 & 0.00 & 0.00 & 0.00 \\
\hline \multicolumn{11}{|l|}{$Z:$} \\
\hline $\mathrm{Al}$ & 6.00 & 6.00 & 6.00 & 6.00 & 6.00 & 6.00 & 6.00 & 6.00 & 6.00 & 6.00 \\
\hline $\mathrm{Mg}$ & 0.00 & 0.00 & 0.00 & 0.00 & 0.00 & 0.00 & 0.00 & 0.00 & 0.00 & 0.00 \\
\hline $\mathrm{Cr}$ & 0.00 & 0.00 & 0.00 & 0.00 & 0.00 & 0.00 & 0.00 & 0.00 & 0.00 & 0.00 \\
\hline \multicolumn{11}{|l|}{$Y:$} \\
\hline $\mathrm{Al}$ & 0.63 & 1.06 & 1.38 & 1.14 & 0.97 & 0.99 & 1.27 & 1.14 & 1.11 & 1.04 \\
\hline $\mathrm{Ti}$ & 0.00 & 0.01 & 0.00 & 0.00 & 0.00 & 0.00 & 0.00 & 0.01 & 0.00 & 0.00 \\
\hline $\mathrm{Cr}$ & 0.00 & 0.00 & 0.00 & 0.00 & 0.00 & 0.00 & 0.00 & 0.00 & 0.00 & 0.00 \\
\hline $\mathrm{Mg}$ & 0.89 & 0.00 & 0.00 & 0.00 & 0.03 & 0.06 & 0.01 & 0.03 & 0.00 & 0.00 \\
\hline $\mathrm{Mn}$ & 0.02 & 0.07 & 0.24 & 0.20 & 0.05 & 0.04 & 0.08 & 0.10 & 0.27 & 0.36 \\
\hline $\mathrm{Fe}$ & 1.31 & 0.98 & 0.23 & 0.47 & 1.42 & 1.17 & 0.53 & 0.72 & 0.33 & 0.17 \\
\hline $\mathrm{Li}^{*}$ & 0.14 & 0.89 & 1.14 & 1.18 & 0.52 & 0.74 & 1.10 & 1.00 & 1.29 & 1.43 \\
\hline \multicolumn{11}{|l|}{$X:$} \\
\hline $\mathrm{Ca}$ & 0.02 & 0.01 & 0.03 & 0.03 & 0.01 & 0.01 & 0.03 & 0.03 & 0.03 & 0.05 \\
\hline $\mathrm{Na}$ & 0.48 & 0.80 & 0.69 & 0.75 & 0.55 & 0.74 & 0.78 & 0.76 & 0.76 & 0.77 \\
\hline K & 0.01 & 0.00 & 0.01 & 0.00 & 0.00 & 0.00 & 0.00 & 0.01 & 0.00 & 0.01 \\
\hline $\mathrm{x}_{\square}$ & 0.50 & 0.18 & 0.27 & 0.22 & 0.44 & 0.26 & 0.19 & 0.20 & 0.20 & 0.18 \\
\hline $\mathrm{Na}+\mathrm{K}$ & 0.48 & 0.81 & 0.70 & 0.76 & 0.55 & 0.74 & 0.78 & 0.77 & 0.76 & 0.77 \\
\hline $\mathrm{Na} /(\mathrm{Na}+\mathrm{Ca})$ & 0.97 & 0.98 & 0.96 & 0.96 & 0.99 & 0.99 & 0.96 & 0.97 & 0.96 & 0.94 \\
\hline $\mathrm{Mg}(/ \mathrm{Fe}+\mathrm{Mg})$ & 0.40 & 0.00 & 0.00 & 0.01 & 0.02 & 0.05 & 0.02 & 0.04 & 0.01 & 0.00 \\
\hline $\mathrm{Y}$ site $\mathrm{Fe}+\mathrm{Mg}+\mathrm{Mn}$ & 2.23 & 1.05 & 0.48 & 0.67 & 1.50 & 1.27 & 0.62 & 0.85 & 0.60 & 0.53 \\
\hline $\mathrm{x}_{\square} /\left(\mathrm{x}_{\square}+\mathrm{Na}\right)$ & 0.51 & 0.18 & 0.28 & 0.22 & 0.45 & 0.26 & 0.19 & 0.21 & 0.21 & 0.19 \\
\hline
\end{tabular}

this third group occur in veinlets crossing the amblygonite crystals, indicating that they are not part of the early primary assemblage, but they belong to a late stage of crystallization. Similar suites of phosphates have been described from LCTtype pegmatites (Eagle et al. 2015). In addition to this phosphate suite, other phosphate minerals occurring in veinlets cross-cutting through all the primary minerals are $\mathrm{Mn}-\mathrm{Fe}$ phosphates and U-bearing phosphates. The varied EDS spectra observed did not permit to identify all these minerals but suggest that several different phosphate mineral phases are 

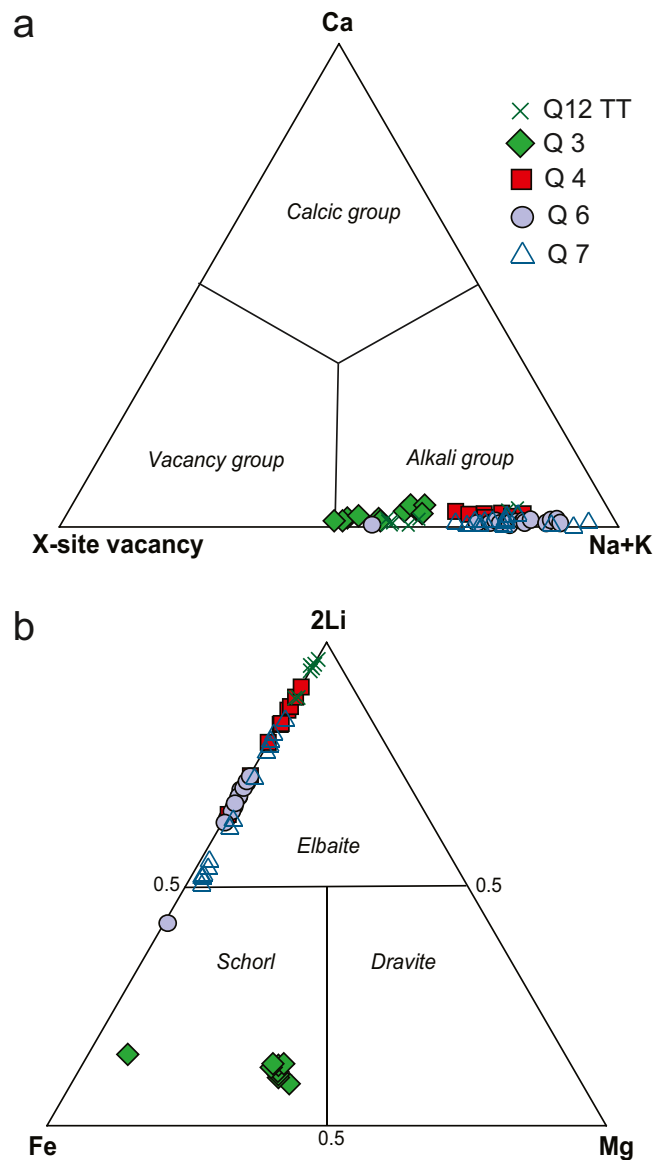

Fig. 5 Ternary classification diagrams (after Henry et al. 2011) for the composition of tourmaline from El Quemado pegmatites based on: (a) X site occupancy; (b) and dravite-schorl-elbaite subsystem of the alkali group

present, as already reported for other LCT-pegmatite rocks. The textural evidence that these phosphate mineral phases post-date all primary minerals indicates that they are secondary phases.

Rare grains of Fe-Mn-W oxide minerals, the sulfides pyrite and sphalerite, beryl and an unidentified Cs-bearing silicate mineral (pollucite?) have been found only in the Tres Tetas pegmatites, enclosed in the primary minerals Al-phosphate, tourmaline and quartz.

Finally, minor clays (mixed-layers illite-smectite, Fig. 4b) have been found in veinlets or as thin rims at the contact between main minerals, suggesting a modest circulation of possibly supergene fluids in low-T alteration neutral-alkaline environment.

\section{Paragenetic successions and geothermometric calculations}

By means of the textural relationships between the different identified mineral components (cross-cutting veinlets, inclusion relationships) and the chemical range displayed by some minerals (tourmaline, $\mathrm{Nb}$-Ta oxides), a paragenetic diagram has been constructed (Fig. 11). The diagram shows the paragenetic evolution from the magmatic-pegmatite stage to the late hydrothermal stage. The decreasing temperature can be constrained thanks to mineral geothermometry in the magmatic and hydrothermal stages.

The crystallization temperature of pegmatites was estimated by two-feldspar geothermometry, which has been applied to coexisting plagioclase and non-perthitic alkali feldspar in sample Q6 (Santa Elena pegmatite). The results of Fuhrman and Lindsley (1988) and Elkins and Grove (1990) twofeldspar geothermometers indicate temperature around $340{ }^{\circ} \mathrm{C}$; the equations of Putirka (2008) suggest a temperature of crystallization of $315 \pm 30{ }^{\circ} \mathrm{C}$ (eq. 27b) and $395 \pm 30{ }^{\circ} \mathrm{C}$ (eq. global regression 42 experiments).

Chlorite composition has been used to have inferences on the temperature during the late hydrothermal stage. Chlorite is a relevant indicator of the rock history, because its large compositional variation is sensitive to the formation conditions (i.e., pressure, temperature, redox conditions, bulk-rock and fluid composition). Therefore, chlorite composition is the basis of many geothermometers that are commonly applied in a variety of geological context (Fulignati 2020; Bourdelle 2021 and reference therein). In this work, both empirical and semiempirical approaches are used for chlorite geothermometry and the obtained results are summarised in Table 8. Among the empirical methods, three different geothermometers of Cathelineau and Nieva (1985, C\&N85), Cathelineau (1988, C88), and Kranidiotis and MacLean (1987, K\&ML87) are used. The geothermometers of C88 and K\&ML87 give similar estimated temperature of formation $\left( \pm 15^{\circ} \mathrm{C}\right)$, with the K\&ML87 geothermometer giving systematically the higher temperatures. The estimated temperatures are very high, with average values of $350{ }^{\circ} \mathrm{C}$ and $370{ }^{\circ} \mathrm{C}$ for $\mathrm{C} 88$ and $\mathrm{K} \& M L 87$ geothermometers, respectively. C\&N85 geothermometer gives lower temperature of formation with an average value of $290{ }^{\circ} \mathrm{C}$. The recent approach of Bourdelle and Cathelineau (2015), which represents a graphical representation of the semi-empirical chlorite geothermometer of Bourdelle et al. (2013), was also used. The analysed chlorite, in the T- $\mathrm{R}^{2+}{ }_{-} \mathrm{Si}$ diagram (Fig. 12) of Bourdelle and Cathelineau (2015), plots between the $200^{\circ} \mathrm{C}$ and $250^{\circ} \mathrm{C}$ isotherms. These temperatures are considerably lower than those estimated with the empirical geothermometers, in particular with the C88 and K\&ML87 ones. We are confident with the estimation carried out with the most recent Bourdelle et al. (2013) geothermometer, as it is best suited for the low temperature chlorites $\left(<350{ }^{\circ} \mathrm{C}\right.$, $P<400 \mathrm{MPa}$ ) typical of low-grade metamorphism and hydrothermal alteration and circumvents bulk rock composition effects (Bourdelle et al. 2013). For these reasons, it has been successfully applied in several recent works concerning temperature estimation of hydrothermal fluid circulation (Harbi et al. 2014; Vasquez et al. 2014; Mamadou et al. 2016; Pant 


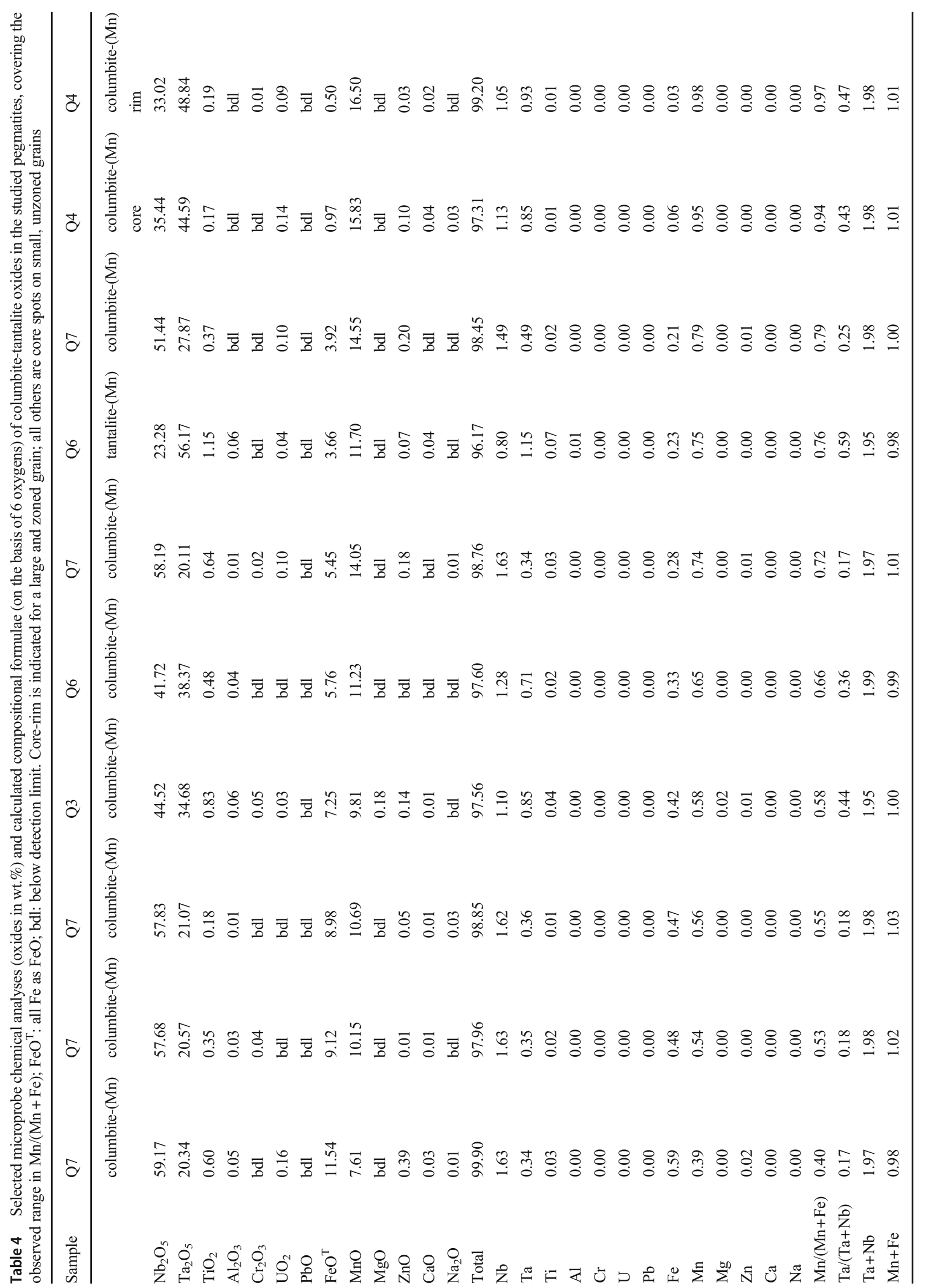




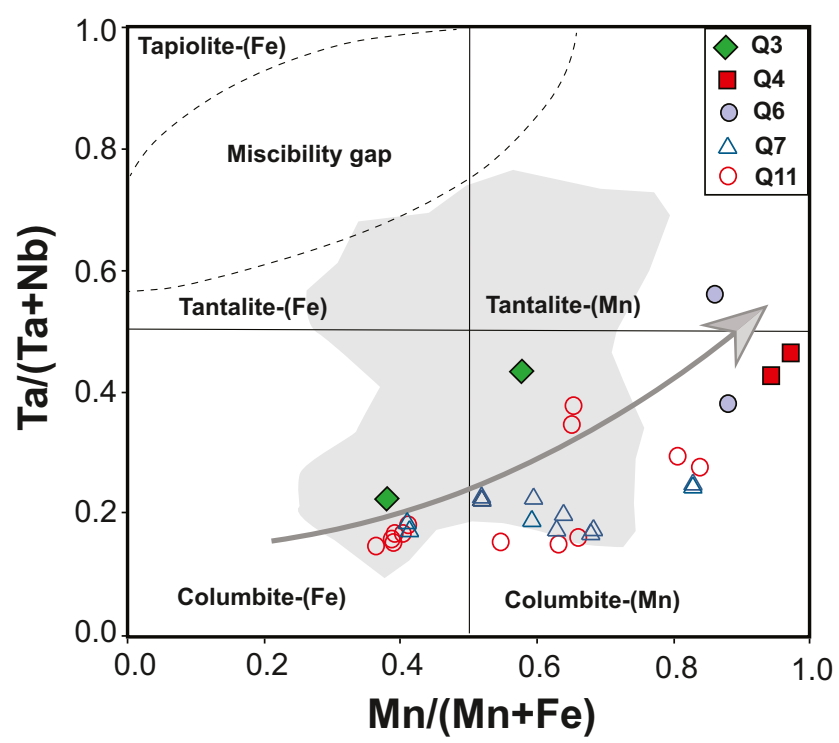

Fig. 6 Chemical composition of the columbite group-minerals of El Quemado pegmatites plotted in the columbite-tantalite quadrilateral classification diagram (after Černý 1989). The miscibility gap is according to Černý et al. (1992). Gray field corresponds to Nb-Ta oxides from Totoral LCT rare-element pegmatite district, San Luis, Argentina (Galliski et al. 2019). Gray arrow suggests the fractionation trend of $\mathrm{Ta} /(\mathrm{Ta}+\mathrm{Nb})$ vs. $\mathrm{Mn} /(\mathrm{Mn}+\mathrm{Fe})$ of columbite group minerals in El Quemado pegmatites

et al. 2019; Raza and Absar 2021). The very high iron content of these chlorites $(\mathrm{Fe} /(\mathrm{Fe}+\mathrm{Mg})=0.99)$ might be the cause of the overestimation of temperature with the empirical geothermometers of C88 and K\&ML87.

\section{Discussion}

The composition of tourmaline, mica, gahnite and CGM in Santa Elena and Tres Tetas pegmatites, in conjunction with textural and paragenetic features at the microscale, are used to give constrains on the petrogenesis of the El Quemado pegmatite district. Furthermore, the secondary mineralogical assemblage and the chemical composition of chlorite are considered, with the aim to constrain the physical conditions occurring during a late hydrothermal stage. Possible metallogenetic implications for rare element resources in the region are, finally, discussed.

\section{Insights into petrogenesis of Santa Elena and Tres Tetas pegmatites}

Tourmaline is a very useful petrogenetic indicator mineral as its major element composition is strongly related to the host rock composition (Henry and Guidotti 1985; Van Hinsberg et al. 2011). On the Al-Fe-Mg diagram (cf. Henry and Guidotti 1985), tourmalines from Santa Elena and Tres Tetas pegmatites cluster at very high $\mathrm{Al}$ and $\mathrm{Fe} / \mathrm{Mg}$ ratios and plot within field 1 (Fig. 10a), suggesting that their formation environments can be assumed those typical of Li-rich granitic pegmatites and aplites. Only tourmalines of the sample Q3, from Santa Elena pegmatites, plot within field 2 representative of Li-poor granitoids, pegmatites and aplites formation environment (Fig. 10a). The tourmalines falling in the field 1 show a clear trend toward the Al vertex (elbaite), with the tourmalines most enriched in Al belonging to Q4 (Santa Elena) and Q12 (Tres Tetas) samples (Fig. 10a). The Al enrichment trend is well shown in Fig. 10b. Following Brown and Wise (2001), the evolution of tourmaline composition from schorl-dravite to elbaite can be taken as an evidence of a progressive fractionation trend, with Tres Tetas (Q12 sample) pegmatite that represents the most differentiated composition. The Q4 sample, in this frame, represents the most evolved composition found in the Santa Elena pegmatite.

The chemical zoning of single tourmaline crystals is modest except for sample Q3, representing, based on tourmaline chemistry, the least evolved composition. In this sample, tourmaline crystals show homogeneous cores ( $\mathrm{MgO} 3.6-3.8 \mathrm{wt} \%$ ) and rims with higher $\mathrm{MgO}$ content (up to $4.26 \mathrm{wt} \%$, Table 3). Similar zonation patterns for $\mathrm{Mg}$ and $\mathrm{Ti}$ are reported for tourmalines from Giraúl Pegmatites, Angola (Gonçalvez et al. 2008), which are interpreted as the recurrent interaction of
Table 5 Selected microprobe chemical analyses of gahnite (oxides in wt\%) and calculated compositional formulae on the basis of 4 oxygens; $\mathrm{FeO}^{\mathrm{T}}$ : all $\mathrm{Fe}$ as $\mathrm{FeO}$; bdl: below detection limit; $\mathrm{Fe}^{3+}$ recalculated from stoichiometry

\begin{tabular}{|c|c|c|}
\hline Sample & Q11 & Q11 \\
\hline & core & core \\
\hline $\mathrm{SiO}_{2}$ & bdl & bdl \\
\hline $\mathrm{TiO}_{2}$ & 0.03 & 0.02 \\
\hline $\mathrm{Al}_{2} \mathrm{O}_{3}$ & 57.70 & 58.33 \\
\hline $\mathrm{Cr}_{2} \mathrm{O}_{3}$ & bdl & bdl \\
\hline $\mathrm{FeO}^{\mathrm{T}}$ & 1.35 & 0.11 \\
\hline $\mathrm{MnO}$ & 0.09 & 0.06 \\
\hline $\mathrm{MgO}$ & 0.04 & 0.01 \\
\hline $\mathrm{ZnO}$ & 42.41 & 41.95 \\
\hline Total & 101.62 & 100.48 \\
\hline $\mathrm{Si}$ & 0.00 & 0.00 \\
\hline $\mathrm{Ti}$ & 0.00 & 0.00 \\
\hline $\mathrm{Al}$ & 2.00 & 2.02 \\
\hline $\mathrm{Cr}$ & 0.00 & 0.00 \\
\hline $\mathrm{Fe}^{3+}$ & 0.00 & 0.00 \\
\hline $\mathrm{Fe}^{2+}$ & 0.03 & 0.00 \\
\hline $\mathrm{Mn}$ & 0.00 & 0.00 \\
\hline $\mathrm{Mg}$ & 0.00 & 0.00 \\
\hline $\mathrm{Zn}$ & 0.92 & 0.91 \\
\hline Glx & 0.00 & 0.00 \\
\hline Spl & 0.00 & 0.00 \\
\hline Ghn & 96.8 & 100.0 \\
\hline $\mathrm{Hc}$ & 3.2 & 0.00 \\
\hline Mag & 0.00 & 0.00 \\
\hline
\end{tabular}


Fig. 7 Binary Zn vs Fe ${ }^{2+}$ (apfu) diagram of gahnite from $\mathrm{El}$ Quemado pegmatites. Dark gray fields show the composition of gahnite from granitic pegmatites of the Pampean Pegmatite Province, Argentina (Heimann et al. 2015); Light grey field shows the composition of gahnite from granitic pegmatites of the Borborema Pegmatitic Province, Brasil (Soares et al. 2007)

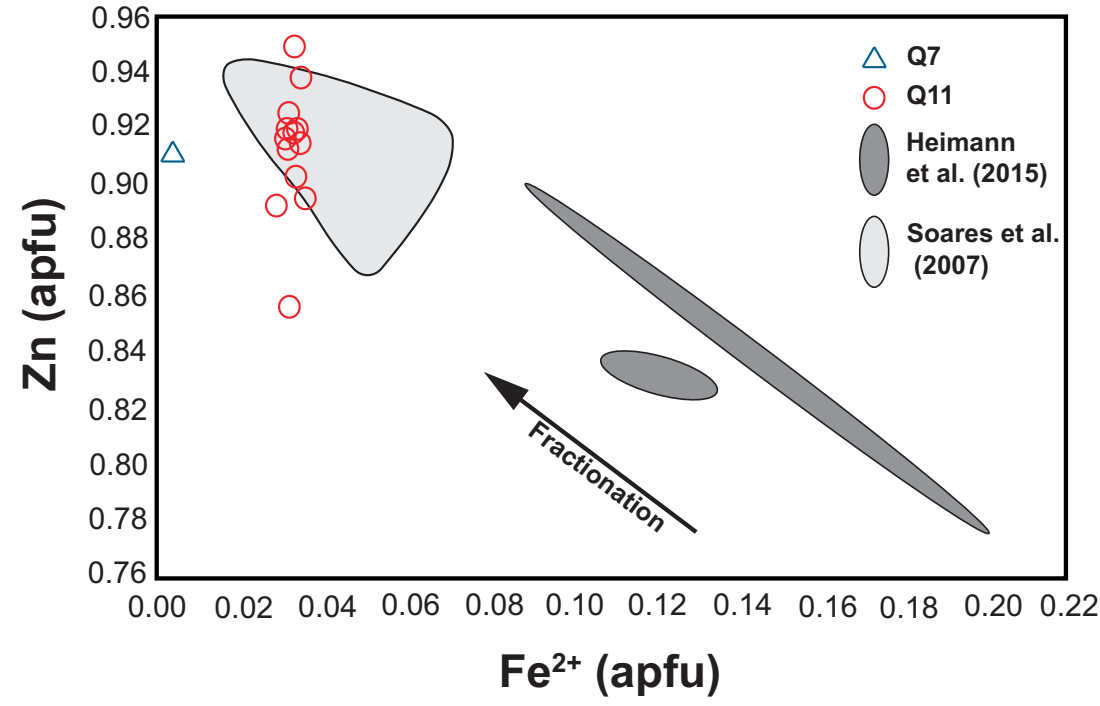

the pegmatitic melt with the host rock at the final stage of pegmatite crystallization.

Based on pegmatite mineralogy, $\mathrm{Zn}$ contents, $\mathrm{Zn} / \mathrm{Fe}^{2+}$ ratios, and coupled $\mathrm{Fe}^{2+}+\mathrm{Mg}$ and $\mathrm{Zn}+\mathrm{Mn}$ values in gahnite from LCT granitic pegmatites from Comechingones and Conlara Districts in central Argentina, Heimann et al. (2015) concluded that the major element composition of gahnite in granitic pegmatites can effectively be used to determine the relative degree of evolution of pegmatite-forming melts. The

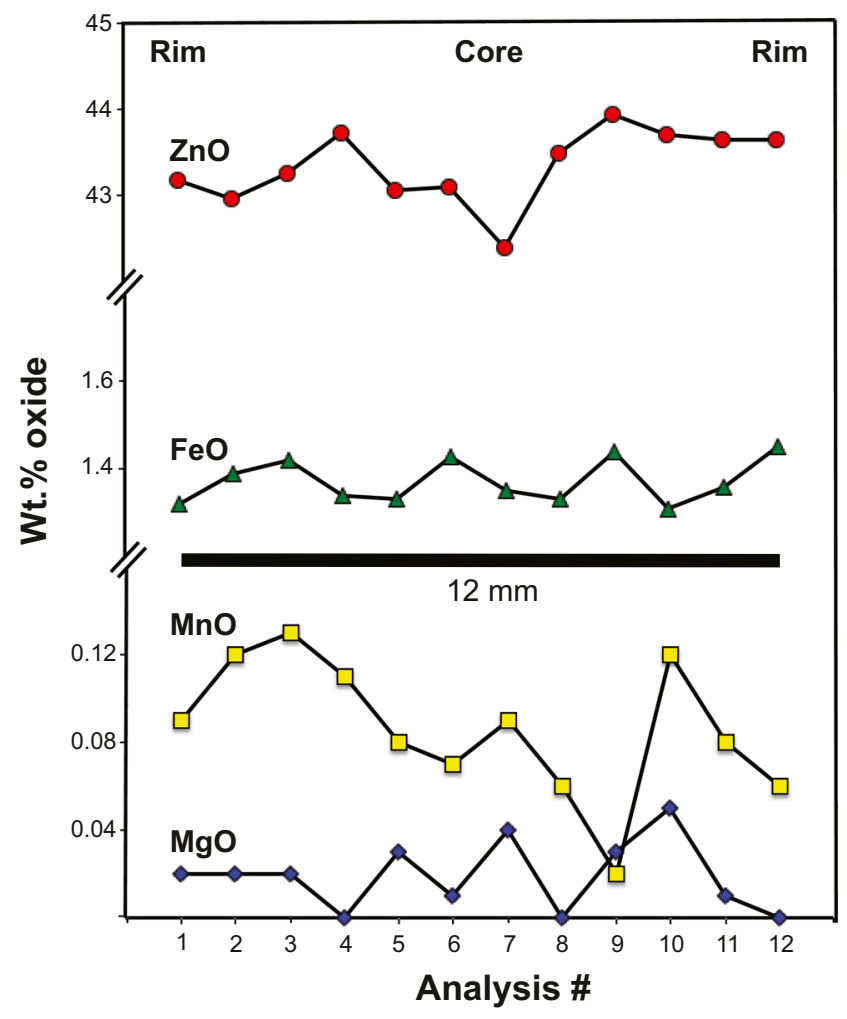

Fig. 8 Compositional profile across a gahnite crystal showing variations between the core and the rim composition of gahnite in the Santa Elena pegmatites is characterized by very high $\mathrm{Zn}$ content and $\mathrm{Zn} / \mathrm{Fe}^{2+}$ ratios (Fig. 7), together with very low $\mathrm{Mg}$ and $\mathrm{Mn}$ contents, indicating that they formed from highly differentiated melts. These melts were, indeed, more evolved than the Pampean Range granitic pegmatites from central Argentina studied by Heimann et al. (2015).

The presence of gahnite as $\mathrm{Zn}$ mineral in the Santa Elena pegmatites indicates a low sulfur activity in the granitic melt, otherwise sphalerite instead of gahnite would have been the common Zn mineral (Černý and Hawthorne 1982). On the other hand, rare sphalerite has been found enclosed in tourmaline (sample Q12) and pyrite within phosphate (sample Q13) in the Tres Tetas samples. Since these scarce sulfides were not found in association to secondary minerals, we suggest that they are primary accessories. The occurrence of primary

Table 6 Selected microprobe chemical analyses (oxides in wt\%) of feldspars in the studied pegmatites and calculated compositional formulae on the basis of 8 oxygens; total $\mathrm{Fe}$ as $\mathrm{FeO}^{\mathrm{T}}$; bdl: below detection limit; $\mathrm{Ab}$ : albite, Mc: microcline

\begin{tabular}{lllllll}
\hline Sample & Q11 & Q12 & Q4 & Q6 & Q6 & Q6 \\
\hline & $\mathrm{Ab}$ & $\mathrm{Ab}$ & $\mathrm{Ab}$ & $\mathrm{Ab}$ & $\mathrm{Mc}$ & $\mathrm{Mc}$ \\
$\mathrm{SiO}_{2}$ & 69.25 & 69.78 & 69.72 & 69.23 & 65.34 & 65.56 \\
$\mathrm{Al}_{2} \mathrm{O}_{3}$ & 19.90 & 20.00 & 19.09 & 19.51 & 17.01 & 17.31 \\
$\mathrm{FeO}^{\mathrm{T}}$ & bdl & bdl & bdl & 0.05 & bdl & 0.03 \\
$\mathrm{CaO}$ & 0.06 & 0.15 & 0.03 & 0.02 & 0.01 & 0.01 \\
$\mathrm{Na} 2 \mathrm{O}$ & 10.71 & 10.18 & 10.73 & 11.41 & 0.33 & 0.36 \\
$\mathrm{~K}_{2} \mathrm{O}$ & 0.02 & 0.10 & 0.12 & 0.06 & 16.51 & 16.53 \\
$\mathrm{Total}$ & 99.93 & 100.21 & 99.68 & 100.28 & 99.20 & 99.81 \\
$\mathrm{An}$ & 0.30 & 0.78 & 0.14 & 0.11 & 0.05 & 0.07 \\
$\mathrm{Ab}$ & 99.60 & 98.57 & 99.16 & 99.57 & 2.94 & 3.23 \\
$\mathrm{Or}$ & 0.10 & 0.65 & 0.71 & 0.32 & 97.01 & 96.71 \\
\hline
\end{tabular}


Table 7 Selected microprobe chemical analyses (oxides in wt\%) and calculated compositional formulae (cation proportions on the basis of 22 oxygens) of micas in the El Quemado pegmatites; bdl: below detection limit. *Li calculated for Q7 micas, which approach the parameters required for the methodology, according to Tischendorf et al. (1997, 2004)

\begin{tabular}{|c|c|c|c|c|c|c|c|c|c|c|}
\hline Sample & Q6 & Q6 & Q6 & Q6 & Q6 & Q11 & Q11 & Q7 & Q7 & Q7 \\
\hline $\mathrm{SiO}_{2}$ & 47.33 & 46.51 & 51.05 & 47.29 & 47.31 & 48.69 & 48.20 & 55.11 & 55.10 & 55.53 \\
\hline $\mathrm{TiO}_{2}$ & 0.04 & bdl & 0.01 & bdl & bdl & bdl & 0.03 & bdl & 0.01 & 0.00 \\
\hline $\mathrm{Al}_{2} \mathrm{O}_{3}$ & 34.70 & 35.74 & 28.96 & 35.06 & 36.02 & 36.44 & 37.84 & 25.19 & 21.02 & 21.34 \\
\hline $\mathrm{Cr}_{2} \mathrm{O}_{3}$ & bdl & 0.06 & 0.02 & 0.03 & bdl & 0.01 & bdl & bdl & 0.00 & 0.00 \\
\hline $\mathrm{FeO}^{\mathrm{T}}$ & 0.33 & 0.34 & 0.45 & 0.50 & 0.44 & 0.21 & 0.17 & 1.40 & 3.05 & 2.86 \\
\hline $\mathrm{MnO}$ & 0.06 & bdl & 0.11 & 0.10 & 0.01 & 0.06 & 0.05 & 0.16 & 0.28 & 0.26 \\
\hline $\mathrm{MgO}$ & 0.06 & 0.02 & 0.04 & 0.02 & 0.01 & 0.08 & 0.06 & 0.08 & 0.16 & 0.15 \\
\hline $\mathrm{CaO}$ & 0.05 & 0.06 & 0.07 & bdl & 0.04 & 0.06 & 0.03 & 0.04 & 0.01 & 0.04 \\
\hline $\mathrm{Na}_{2} \mathrm{O}$ & 0.21 & 0.16 & 0.08 & 0.25 & 0.18 & 0.04 & bdl & 0.06 & 0.07 & 0.04 \\
\hline $\mathrm{K}_{2} \mathrm{O}$ & 11.17 & 11.16 & 11.41 & 10.27 & 10.44 & 9.49 & 8.87 & 10.03 & 10.05 & 10.18 \\
\hline $\mathrm{Li}_{2}$ Ocalc* & & & & & & & & 6.26 & 6.26 & 6.39 \\
\hline Total & 93.95 & 94.05 & 92.2 & 93.52 & 94.45 & 95.08 & 95.25 & 98.33 & 96.01 & 96.75 \\
\hline $\mathrm{Si}$ & 6.36 & 6.24 & 6.96 & 6.35 & 6.29 & 6.36 & 6.26 & 6.1 & 6.27 & 6.26 \\
\hline $\mathrm{Al}(\mathrm{IV})$ & 1.64 & 1.76 & 1.04 & 1.65 & 1.71 & 1.64 & 1.74 & 1.9 & 1.73 & 1.74 \\
\hline $\mathrm{Al}(\mathrm{VI})$ & 3.85 & 3.90 & 3.62 & 3.89 & 3.93 & 3.98 & 4.06 & 1.38 & 1.08 & 1.09 \\
\hline $\mathrm{Ti}$ & 0.00 & 0.00 & 0.00 & 0.00 & 0.00 & 0.00 & 0.00 & 0.00 & 0.00 & 0.00 \\
\hline $\mathrm{Fe}$ & 0.04 & 0.04 & 0.05 & 0.06 & 0.05 & 0.02 & 0.02 & 0.13 & 0.29 & 0.27 \\
\hline $\mathrm{Mn}$ & 0.01 & 0.00 & 0.01 & 0.01 & 0.00 & 0.01 & 0.01 & 0.01 & 0.03 & 0.02 \\
\hline $\mathrm{Mg}$ & 0.01 & 0.00 & 0.01 & 0.00 & 0.00 & 0.02 & 0.01 & 0.01 & 0.03 & 0.03 \\
\hline $\mathrm{Cr}$ & 0.00 & 0.01 & 0.00 & 0.00 & 0.00 & 0.00 & 0.00 & 0.00 & 0.00 & 0.00 \\
\hline $\mathrm{Li}$ & & & & & & & & 2.79 & 2.87 & 2.84 \\
\hline Sum [Y] & 3.91 & 3.95 & 3.69 & 3.96 & 3.98 & 4.03 & 4.10 & 4.32 & 4.3 & 4.25 \\
\hline $\mathrm{Ca}$ & 0.01 & 0.01 & 0.01 & 0.00 & 0.01 & 0.01 & 0.00 & 0.01 & 0.01 & 0.01 \\
\hline $\mathrm{Na}$ & 0.05 & 0.04 & 0.02 & 0.07 & 0.05 & 0.01 & 0.00 & 0.02 & 0.01 & 0.01 \\
\hline K & 1.91 & 1.91 & 1.98 & 1.76 & 1.77 & 1.58 & 1.47 & 1.73 & 1.42 & 1.58 \\
\hline Sum $[\mathrm{X}]$ & 1.97 & 1.96 & 2.01 & 1.83 & 1.83 & 1.60 & 1.47 & 1.76 & 1.44 & 1.60 \\
\hline
\end{tabular}

sulfides may suggest slightly different sulfide activity in the two pegmatite groups, despite gahnite seems ubiquitous, or the fact that sulfide activity may have changed during evolution of these pegmatites, with initially moderate values,
Fig. 9 Chemical composition of micas from El Quemado pegmatites shown on ternary diagram $\mathrm{Al}-\mathrm{R}^{2+}-\mathrm{Si}$ (Monier and Robert 1986). $\mathrm{R}^{2+}=\mathrm{Fe}^{2+}+\mathrm{Mn}^{2+}$ $+\mathrm{Mg}^{2+}$

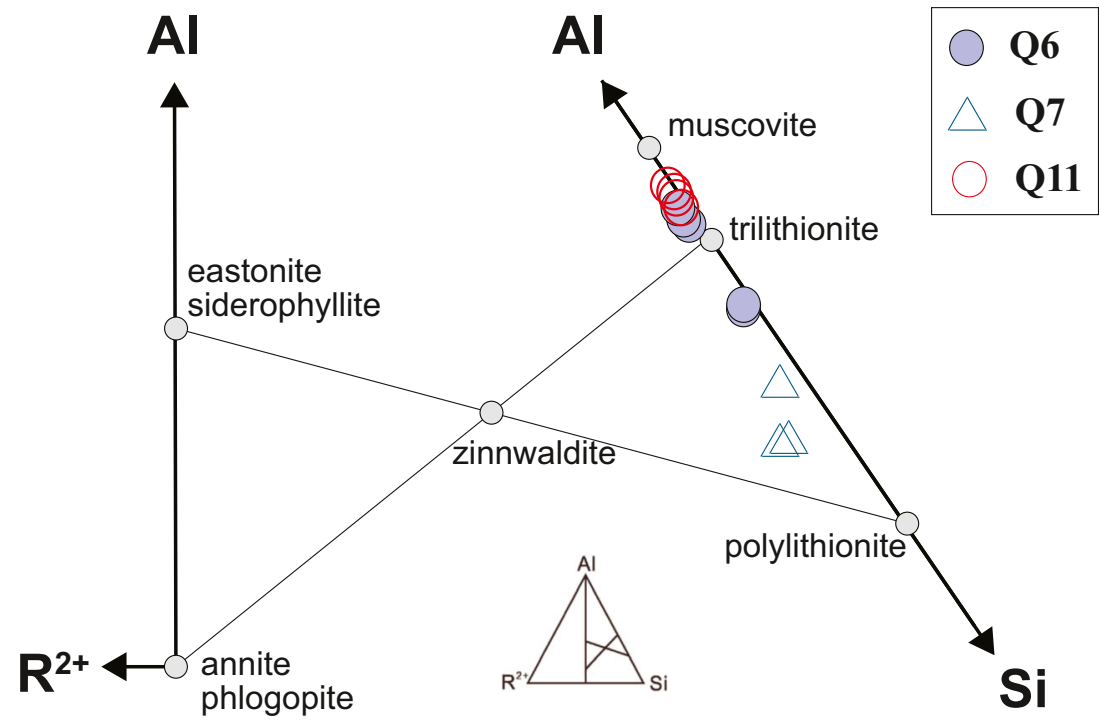


Table 8 Selected chemical analyses of chlorite (oxides in $\mathrm{wt} \%$ ) and calculated composition formulae (on the basis of 28 oxygens) for the sample Q7 of Santa Elena pegmatite; bdl: below detection limit; total iron as $\mathrm{FeO}^{\mathrm{T}}$.

Temperature obtained by the application of chlorite geothermometers $\mathrm{C} \& \mathrm{~N} 85$

(Cathelineau and Nieva 1985), C88 (Cathelineau 1988),

K\&ML87 (Kranidiotis and MacLean 1987)

\begin{tabular}{|c|c|c|c|c|c|c|c|c|c|}
\hline Sample & Q7 & Q7 & Q7 & Q7 & Q7 & Q7 & Q7 & Q7 & Q7 \\
\hline $\mathrm{SiO}_{2}$ & 24.06 & 23.49 & 24.02 & 23.21 & 24.37 & 23.55 & 23.99 & 23.68 & 23.48 \\
\hline $\mathrm{TiO}_{2}$ & bdl & 0.01 & bdl & bdl & 0.01 & 0.02 & bdl & 0.02 & bdl \\
\hline $\mathrm{Al}_{2} \mathrm{O}_{3}$ & 22.08 & 21.89 & 21.31 & 22.33 & 21.76 & 21.26 & 21.77 & 21.85 & 21.98 \\
\hline $\mathrm{Cr}_{2} \mathrm{O}_{3}$ & 0.01 & bdl & bdl & 0.03 & 0.03 & bdl & 0.02 & 0.03 & 0.03 \\
\hline $\mathrm{FeO}^{\mathrm{T}}$ & 41.15 & 41.98 & 42.02 & 41.55 & 41.84 & 42.10 & 41.64 & 40.66 & 41.77 \\
\hline $\mathrm{MnO}$ & 0.63 & 0.54 & 0.50 & 0.54 & 0.50 & 0.50 & 0.51 & 0.56 & 0.47 \\
\hline $\mathrm{MgO}$ & 0.29 & 0.30 & 0.29 & 0.30 & 0.35 & 0.28 & 0.29 & 0.30 & 0.30 \\
\hline $\mathrm{CaO}$ & 0.04 & 0.08 & 0.04 & 0.15 & 0.07 & 0.05 & 0.15 & 0.03 & 0.07 \\
\hline $\mathrm{Na}_{2} \mathrm{O}$ & 0.04 & 0.14 & 0.04 & 0.01 & 0.04 & 0.06 & 0.08 & 0.10 & 0.02 \\
\hline $\mathrm{K}_{2} \mathrm{O}$ & bdl & bdl & bdl & 0.03 & 0.01 & 0.02 & 0.01 & 0.01 & bdl \\
\hline Total & 88.3 & 88.43 & 88.22 & 88.15 & 88.98 & 87.84 & 88.46 & 87.24 & 88.12 \\
\hline $\mathrm{Si}$ & 5.49 & 5.40 & 5.52 & 5.34 & 5.53 & 5.46 & 5.49 & 5.48 & 5.40 \\
\hline $\mathrm{Al}(\mathrm{IV})$ & 2.51 & 2.60 & 2.48 & 2.66 & 2.47 & 2.54 & 2.51 & 2.52 & 2.60 \\
\hline $\mathrm{Al}(\mathrm{VI})$ & 3.44 & 3.32 & 3.30 & 3.39 & 3.36 & 3.26 & 3.36 & 3.43 & 3.36 \\
\hline $\mathrm{Ti}$ & 0.00 & 0.00 & 0.00 & 0.00 & 0.00 & 0.00 & 0.00 & 0.00 & 0.00 \\
\hline $\mathrm{Fe}$ & 7.86 & 8.06 & 8.08 & 7.99 & 7.94 & 8.15 & 7.96 & 7.86 & 8.03 \\
\hline $\mathrm{Mn}$ & 0.12 & 0.11 & 0.10 & 0.11 & 0.10 & 0.10 & 0.10 & 0.11 & 0.09 \\
\hline $\mathrm{Mg}$ & 0.10 & 0.10 & 0.10 & 0.10 & 0.12 & 0.10 & 0.10 & 0.10 & 0.10 \\
\hline $\mathrm{Cr}$ & 0.00 & 0.00 & 0.00 & 0.01 & 0.01 & 0.00 & 0.00 & 0.01 & 0.01 \\
\hline $\mathrm{Ca}$ & 0.01 & 0.02 & 0.01 & 0.04 & 0.02 & 0.01 & 0.04 & 0.01 & 0.02 \\
\hline $\mathrm{Na}$ & 0.02 & 0.06 & 0.02 & 0.00 & 0.02 & 0.03 & 0.04 & 0.04 & 0.01 \\
\hline K & 0.00 & 0.00 & 0.00 & 0.01 & 0.00 & 0.01 & 0.00 & 0.00 & 0.00 \\
\hline $\mathrm{Fe} /(\mathrm{Fe}+\mathrm{Mg})$ & 0.99 & 0.99 & 0.99 & 0.99 & 0.99 & 0.99 & 0.99 & 0.99 & 0.99 \\
\hline oct. vacancy & 0.49 & 0.41 & 0.43 & 0.41 & 0.48 & 0.39 & 0.48 & 0.49 & 0.41 \\
\hline $\mathrm{C} \& \mathrm{~N} 85\left({ }^{\circ} \mathrm{C}\right)$ & 284 & 294 & 281 & 300 & 280 & 287 & 284 & 285 & 294 \\
\hline $\mathrm{C} 88\left({ }^{\circ} \mathrm{C}\right)$ & 340 & 357 & 337 & 366 & 334 & 347 & 344 & 344 & 357 \\
\hline K\&ML87 $\left({ }^{\circ} \mathrm{C}\right)$ & 357 & 367 & 354 & 373 & 353 & 361 & 357 & 359 & 367 \\
\hline
\end{tabular}

allowing the formation of scarce sulfides, and lower values in the final stages, favoring the formation of gahnite.

The CGM in the Santa Elena pegmatite exhibit an evolutionary trend similar to that shown by this mineral group in Black Mountain and Kolmozero pegmatites (Brown and Wise 2001; Badanina et al. 2015) and in the Separation Rapids pegmatite fields (the "manganoan trend", Tindle and Breaks $2000)$, consisting in a progressive increase in $\mathrm{Mn} /(\mathrm{Mn}+\mathrm{Fe})$ subsequently accompanied by an increase in $\mathrm{Ta} /(\mathrm{Ta}+\mathrm{Nb})$ ratio (Fig. 6). This trend is not evident in the Sierras de San Luis pegmatites (central Argentina), whose CGM composition shows notable variations in $\mathrm{Mn} /(\mathrm{Mn}+\mathrm{Fe})$ and $(\mathrm{Ta} / \mathrm{Ta}+\mathrm{Nb})$ (Galliski and Černý 2006; Galliski et al. 2019). Following Černý $(1989,1992)$, the trend depicted by the variation of the $\mathrm{Mn} /(\mathrm{Mn}+\mathrm{Fe})$ and $\mathrm{Ta} /(\mathrm{Ta}+\mathrm{Nb})$ ratios of Santa Elena pegmatites is typical of the lepidolite and/or spodumene (F-rich) subtype of rare-element granitic pegmatites. The $\mathrm{Nb} / \mathrm{Ta}$ ratio of the melt was high throughout the evolution of Santa Elena and Tres Tetas pegmatites, and although melt composition ultimately evolved toward Ta enrichment, $\mathrm{Nb}$ remained dominant over Ta. Several papers (see Ercit 2005 and reference therein) suggest that Ta would increase gradually at the expense of $\mathrm{Nb}$ during melt evolution. This could be explained by the lower solubility of columbite-(Mn) in peraluminous granite/pegmatite melts (Linnen and Keppler 1997) in comparison with tantalite-(Mn). More difficult is the explanation of the increasing $\mathrm{Mn} /(\mathrm{Mn}+\mathrm{Fe})$ ratio with fractionation (Beurlen et al. 2008). The difficulty arises because the solubility of the Fe-rich members of the CGM in the melt is larger than of Mn-rich members (Linnen 2004). This fractionation trend must, therefore, be controlled by other factors. Two possible explanations have been proposed for interpreting the controlling factors that lead to the fractionation of Fe from Mn in CGM: (i) the first one is that co-existing phases competing with CGM for Fe (i.e., tourmaline, Fe-phosphates) in the pegmatites deplete Fe in CGM during fractionation, leading to Mn-rich end-members (Raimbault 1998; Van Lichtervelde et al. 2007; Beurlen et al. 2008); (ii) the second one suggests that an increased alkali-fluoride activity promotes the extreme $\mathrm{Fe}-\mathrm{Mn}$ fractionation before the onset of Ta enrichment, instead of a competing mineral phase control (Tindle and Breaks 2000; Černý et al. 2004; Wise et al. 2012). 


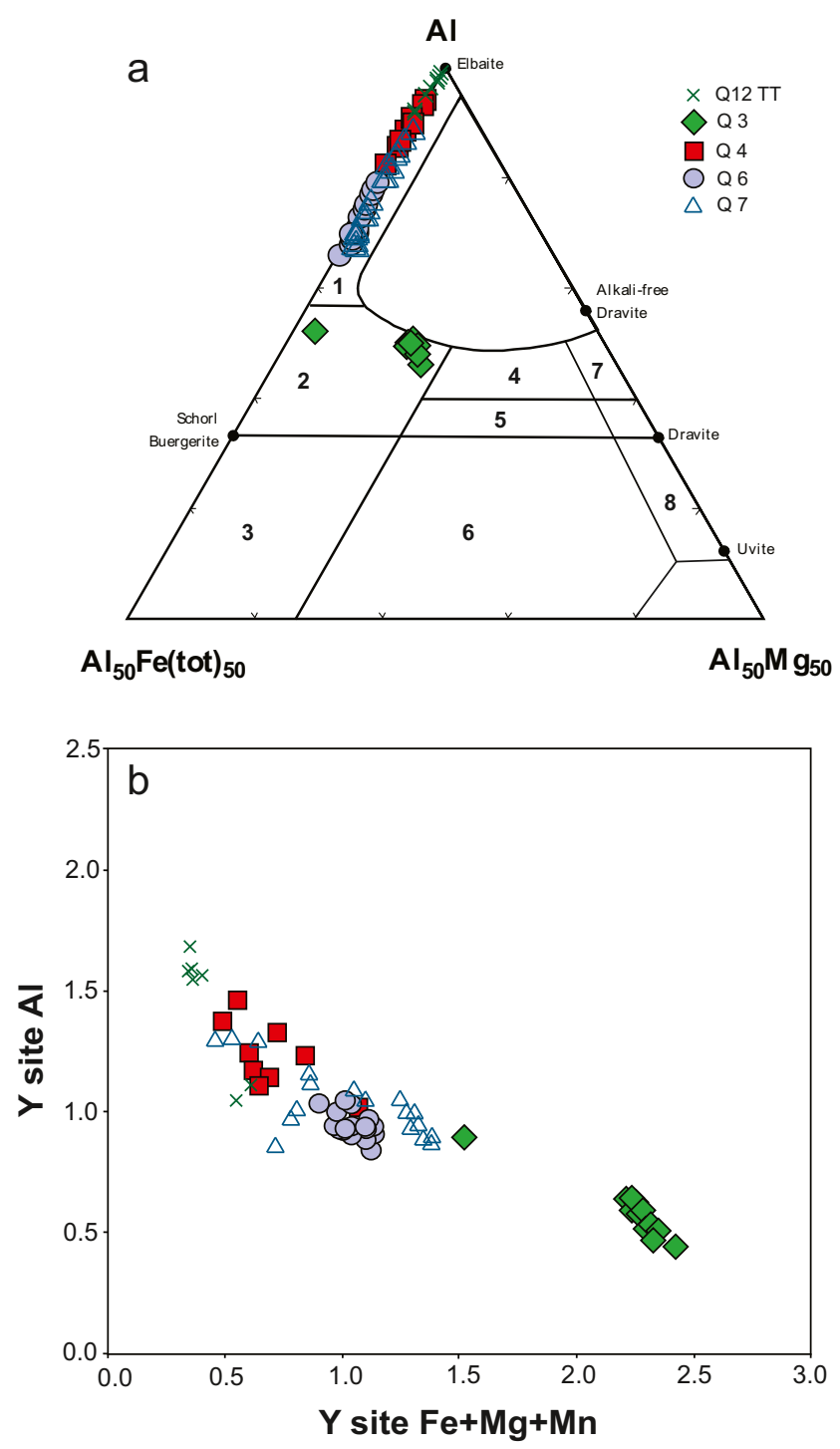

Fig. 10 A. Diagram Al-Fe(tot)-Mg for tourmaline from El Quemado pegmatites, with fields from Henry and Guidotti (1985) for discrimination of the different tourmaline-bearing rock types. Analysis in Table 5. (1) Lirich granitoid pegmatites and aplites, (2) Li-poor granitoids and their associated pegmatites and aplites, (3) $\mathrm{Fe}^{3+}$-rich quartz-tourmaline rocks (hydrothermally altered granites), (4) Metapelites and metapsammites coexisting with an Al-saturating phase, (5) Metapelites and metapsammites not coexisting with an Al-saturating phase (6) $\mathrm{Fe}^{3+}$-rich quartz-tourmaline rocks, calc-silicate rocks, and metapelites (7) Low-Ca meta-ultramafics and $\mathrm{Cr}, \mathrm{V}$-rich metasediments, and (8) metacarbonates and meta-pyroxenite. B. Plot of $\mathrm{Y}$-site $\mathrm{Al}$ versus the sum of $\mathrm{Y}$-site $\mathrm{R}^{2+}$ $(\mathrm{Fe}+\mathrm{Mg}+\mathrm{Mn})$ of the tourmalines from $\mathrm{El}$ Quemado pegmatites

In the Santa Elena pegmatites, the occurrence of quite abundant tourmaline and Fe-bearing phosphates may support the first explanation, although we cannot exclude a possible role played by fluorine activity increase with melt evolution.

Low temperature of crystallization, below $400{ }^{\circ} \mathrm{C}$, is suggested by the values obtained by coexisting albite and nonperthitic microcline in one of the Santa Elena samples. This

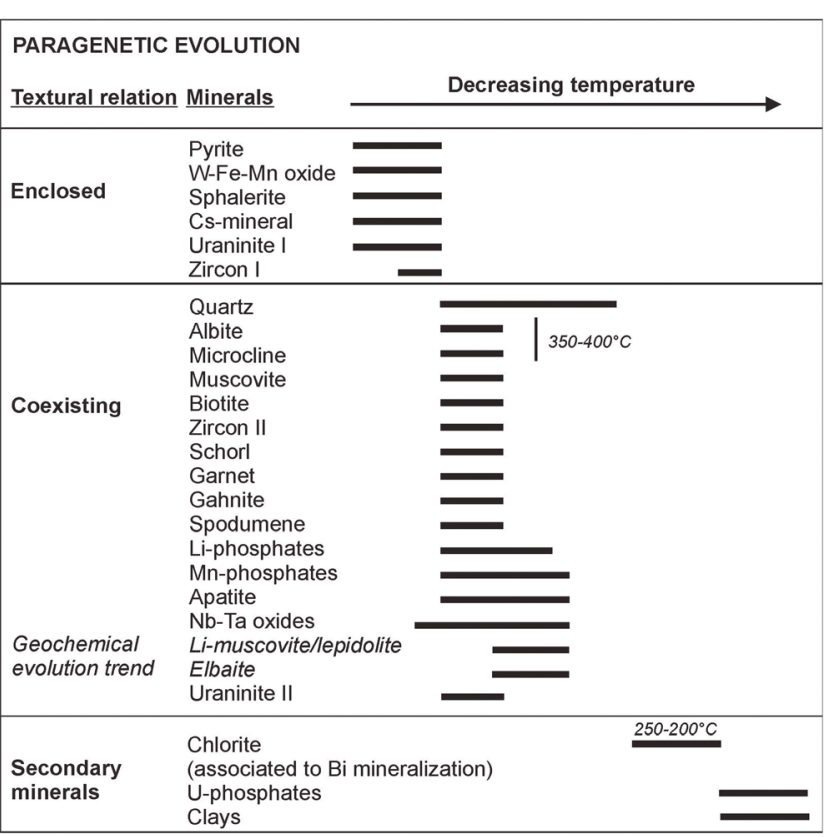

Fig. 11 Paragenetic diagram summarizing the evolution of the mineral associations in the studied El Quemado pegmatites

temperature is lower than the hydrous minimum melt temperatures of about $600{ }^{\circ} \mathrm{C}$ suggested for pegmatites by Jahns and Burnham (1969), but agrees with several more recent estimations on Li-bearing, fluid-rich pegmatites based on mineral geothermometry and fluid inclusion data (Nabelek et al. 1992; Tindle and Breaks 2000; Sirbescu and Nabelek 2003; Simmons and Webber 2008; London et al. 2020). The abundance of Li, Cs, B, P and F (as in the case of Santa Elena and Tres Tetas pegmatites) has been experimentally demonstrated to depress, to a significant extent, the liquidus and solidus of hydrous haplogranite systems (Černý, 1991a; London, 1992). These elements can, in fact, affect the melt by appreciably lowering the crystallization temperature, decreasing nucleation rates, decreasing melt polymerization, decreasing viscosity, increasing diffusion rates, and increasing solubility (London, 1992; Simmons and Webber, 2008). Moreover, crystallization temperatures of $350-400{ }^{\circ} \mathrm{C}$, at $2-3 \mathrm{kbar}$, are also suggested by Galliski et al. (1999), based on the stability of Li-bearing mica and spodumene in the Santa Elena pegmatites. These low temperatures, below $400{ }^{\circ} \mathrm{C}$, may correspond to the conditions of crystallization following undercooling to about $250{ }^{\circ} \mathrm{C}$ below the liquidus, as found for similar thin pegmatite dykes by London et al. (2020).

\section{Evidence for a late hydrothermal stage}

Several pegmatite samples show evidence of secondary alteration mineralogical assemblage consisting of veinlets of phosphates, clay minerals, zeolites and, in one Santa Elena sample, chlorite, whose presence can be related to circulation of 
Fig. 12 Chemical composition of chlorites plotted in the $\mathrm{T}-\mathrm{R}^{2+}-\mathrm{Si}$ diagram of Bourdelle and Cathelineau (2015). The isotherms are in $50^{\circ} \mathrm{C}$ steps. Analyses of chlorite are recalculated based on 14 oxygens

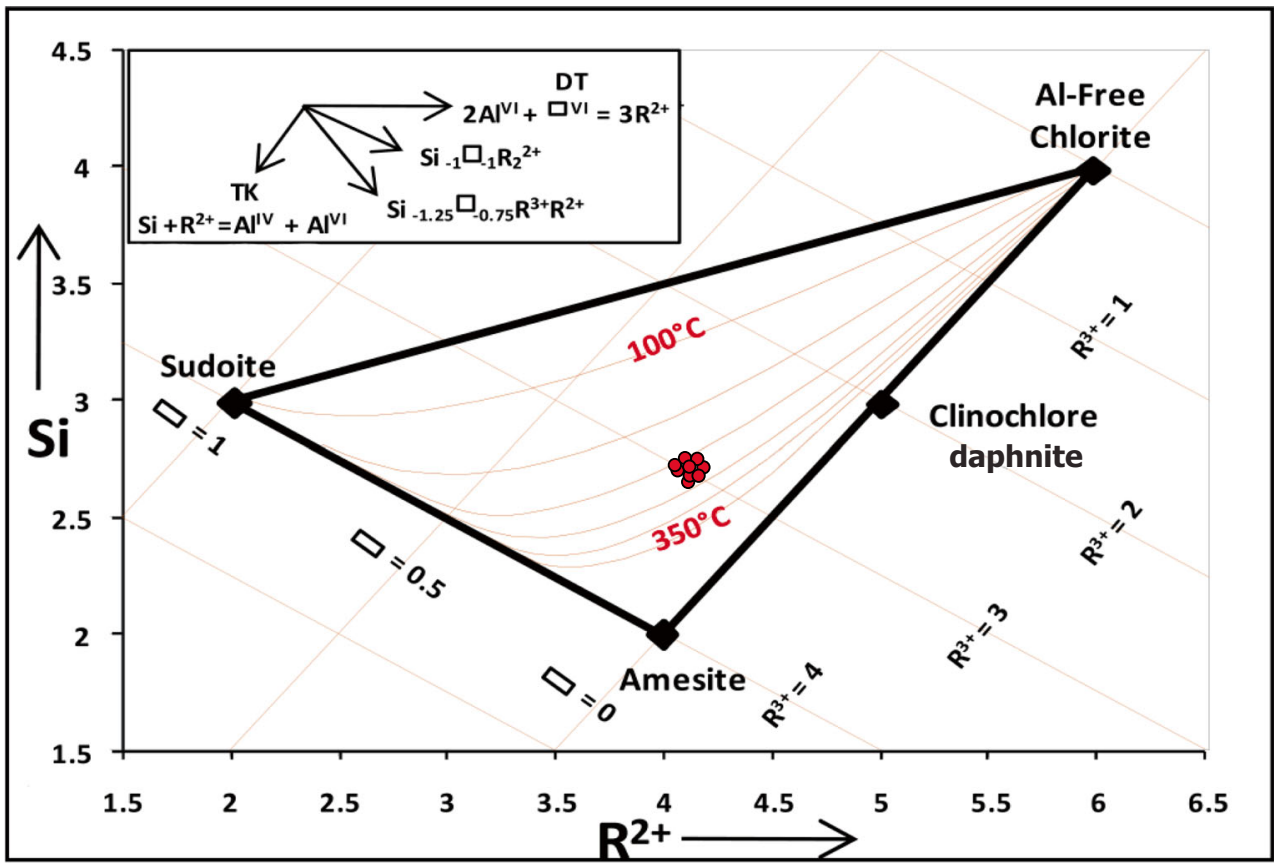

hydrothermal fluids. This chlorite occurrence in aggregates or rosettes is similar to that found in Hagendorf-South pegmatite (Dill 2015). The origin of these chlorite aggregates can be related to a non-pervasive alteration event, carried out by hydrothermal fluids that circulated in the pegmatites. The temperatures during this hydrothermal late stage of alteration of the El Quemado pegmatites, obtained by means of chlorite geothermometry, range from $200^{\circ} \mathrm{C}$ and $250{ }^{\circ} \mathrm{C}$. These values are in accordance with those proposed by Márquez-Zavalía et al. (2012) on the basis of the secondary mineral assemblage found in these rocks, formed by emplectite + bismuthinite + native bismuth.

\section{Implications regarding the metallogenesis of rare element resources in the region}

The Paleozoic pegmatite belt of El Quemado District suffered of uplift, erosion and chemical weathering during Mesozoic and Cenozoic times up to the Present. Those processes made the pegmatites a favourable source for the formation of rare element mineral resources. The concentration of $\mathrm{Nb}-\mathrm{Ta}-\mathrm{Bi}$ minerals accumulated in alluvium deposits can be related to the mineralogical composition and Mesozoic-Cenozoic history of the El Quemado pegmatites. Instead, despite the significant Li resources linked to the occurrence of Li-brine deposits (salars) in the Puna region (Orberger et al. 2015), at present it is not possible to discuss a contribution of $\mathrm{Li}$ leached from the El Quemado Li-rich pegmatites to those notable Li resources. More structural and palaeogeographical studies concerning the evolution of the area during Neogene are needed for shedding light on this topic.

Physical weathering of El Quemado pegmatites contributed to free the $\mathrm{Nb}$-Ta oxides and Bi minerals that accumulated in nearby alluvial environments during Quaternary-Present times. These placer minerals are concentrated naturally in alluvial fans and fluvial plains in Tres Tetas zone, covering more than ca. $0.14 \mathrm{~km}^{2}$ with $\sim 50 \mathrm{~m}$ of thickness, that allow calculating ca. $7,000,000 \mathrm{~m}^{3}$ of sediment with $\mathrm{Nb}$-Ta-Bi minerals. This material was beneficiated downstream in the '40th decade (Galliski 1999). It is important to highlight that in El Quemado zone, south of Santa Elena, the thickness of alluvial sediments is $\sim 20 \mathrm{~m}$ and the surface covered is ca. $2.55 \mathrm{~km}^{2}$. Although no resource estimations have been carried out (Palacio and Devito 1947), considering that $\mathrm{Nb}$-Ta mineral reserves are allocated in only 7 countries, and the high price of these commodities (on the order of $42 \mathrm{USD} / \mathrm{kg}$ of FeNb for 2019 and projected to $50 \mathrm{UDS} / \mathrm{kg} \mathrm{FeNb}$ in 2035) and $\mathrm{Bi}$, the alluvial area of El Quemado District might constitute an exploration target for $\mathrm{Nb}-\mathrm{Ta}-\mathrm{Bi}$ minerals in placers.

\section{Conclusions}

The reconstruction of the paragenetic assemblages and the chemical composition of tourmaline, CGM, gahnite and mica are here used to give insights concerning melt evolution in the Santa Elena and Tres Tetas pegmatites of the El Quemado district. Chemical trends in the composition of these minerals indicate that both these pegmatites crystallized from highly 
differentiated melts, with the Tres Tetas pegmatites representing the most differentiated pegmatite composition. The highly differentiated melts that generated the Santa Elena and Tres Tetas pegmatites were B, F, P-enriched silicate melts that became increasingly enriched in lithium and the high-field-strength elements $\mathrm{Nb}, \mathrm{Ta}, \mathrm{Zr}$, with an increase in the ratio $\mathrm{Ta} /(\mathrm{Ta}+\mathrm{Nb})$, during their crystallization. By comparing the chemical compositions of gahnite of El Quemado district pegmatites with those of other Pampean Range granitic pegmatites from central Argentina, we show that El Quemado pegmatites reached a higher level of differentiation. The occurrence of scarce $\mathrm{Zn}$ sulfides enclosed in the fundamental minerals and of gahnite among the accessories suggests a generally low and probably decreasing sulfur activity along differentiation of the pegmatite melts. The estimated pegmatite crystallization temperature is below $400{ }^{\circ} \mathrm{C}$, confirming the low temperature of pegmatite melts with similar composition ( $\mathrm{Li}, \mathrm{F}, \mathrm{B}, \mathrm{P}$-enriched) proposed in the previous literature. This low temperature may correspond to crystallization under strong undercooling conditions. In some cases, it has been possible to show evidence of late (postmagmatic), non-pervasive, hydrothermal alteration, which developed at temperature ranging from $200^{\circ}$ and $250^{\circ} \mathrm{C}$.

The paragenesis and the mineral chemistry of these pegmatites provide, also, some implications regarding the minerogenesis of the $\mathrm{Nb}$-Ta resources of the region. In this framework, the $\mathrm{Nb}$-Ta oxide placer deposits formed in alluvial environment during Quaternary-Present times can be considered the result of the physical weathering of El Quemado pegmatites, which contributed to free the $\mathrm{Nb}$ - $\mathrm{Ta}$ oxides present in their primary mineralogical assemblage.

\begin{abstract}
Acknowledgements The manuscript benefited from the review of two anonymous referees whose comments and suggestions helped to improve the quality and the clarity of the manuscript. Many thanks are due to the Associate Editor Prof. Shah Wali Faryad for his comments and for the editorial handling. The authors thank F. Colarieti, R. Ishak and A. Risplendente for technical support. The Faculty of Natural Sciences (Facultad de Ciencias Naturales) and the Investigation Project 2343/0 (Investigation Consul, National University of Salta) are gratefully acknowledged for economic and academic support. The research was also supported by the University of Pisa, within the Visiting Fellows Program of Earth Science Department of Pisa and PRA_2018_41 "Georisorse e Ambiente" (resp. S. Raneri). The research was carried out within the International Cooperation Agreement for 2016-2021 between the University of Salta and University of Pisa.
\end{abstract}

Availability of data and materials All data presented in the text of the article are fully available without restriction from authors upon request. Code availability is not applicable.

Authors' contributions VLA conceived the research. VLA and MA carried out the field sampling and field data collection. All authors designed and carried out the analytical data collection. VLA and PF drafted the manuscript. All authors contributed to data interpretation, discussion, and revision of the manuscript and to the final editing.
Funding Open access funding provided by Università di Pisa within the CRUI-CARE Agreement. The authors received economic support from the Faculty of Natural Sciences (Facultad de Ciencias Naturales) and the Investigation Project 2343/0 (Investigation Consul, National University of Salta). The research was also funded by the University of Pisa, within the Visiting Fellows Program of Earth Science Department of Pisa and PRA_2018_41 "Georisorse e Ambiente" (resp. S. Raneri). The research was carried out within the International Cooperation Agreement for 2016-2021 between the University of Salta and University of Pisa.

\section{Declarations}

Competing interests The authors declare that they have no competing interests.

Open Access This article is licensed under a Creative Commons Attribution 4.0 International License, which permits use, sharing, adaptation, distribution and reproduction in any medium or format, as long as you give appropriate credit to the original author(s) and the source, provide a link to the Creative Commons licence, and indicate if changes were made. The images or other third party material in this article are included in the article's Creative Commons licence, unless indicated otherwise in a credit line to the material. If material is not included in the article's Creative Commons licence and your intended use is not permitted by statutory regulation or exceeds the permitted use, you will need to obtain permission directly from the copyright holder. To view a copy of this licence, visit http://creativecommons.org/licenses/by/4.0/.

\section{References}

Badanina EV, Sitnikova MA, Gordienko VV, Melcher F, Gabler H-E, Lodziak J, Syritzo LF (2015) Mineral chemistry of columbitetantalite from spodumene pegmatites of Kolmozero, Kola peninsula (Russia). Ore Geol Rev 64:720-735

Batchelor RA, Kinnaird JA (1984) Gahnite composition compared. Mineral Mag 48:425-429

Bayliss P (1975) Nomenclature of the trioctahedral chlorites. Can Mineral 13:178-180

Beurlen H, Da Silva MRR, Thomas R, Soares DR, Olivier P (2008) Nb$\mathrm{Ta}-(\mathrm{Ti}-\mathrm{Sn})$ oxide mineral chemistry as tracer of rare-element granitic pegmatite fractionation in the Borborema Province, northeastern Brazil. Mineral Deposita 43:207-228

Blasco G, Zappettini FO, Hongn F (1996) Hoja Geológica San Antonio de los Cobres, 2566-I, Provincias de Jujuy y Salta, República Argentina. Bol. 217, 126 pp., Subsecret. de Minería de la Nación, Dir. Nac. Serv. Geol., Buenos Aires

Bourdelle F (2021) Low-temperature chlorite geothermometry and related recent analytical advances: a review. Minerals 11:130

Bourdelle F, Cathelineau M (2015) Low-temperature chlorite geothermometry: a graphical representation based on a T-R2 ${ }^{+}-\mathrm{Si}$ diagram. Eur J Mineral 27:617-626

Bourdelle F, Parra T, Chopin C, Beyssac O (2013) A new chlorite geothermometer for diagenetic to low-grade metamorphic conditions. Contrib Mineral Petrol 165:723-735

Breaks FW, Selway JB, Tindle AG (2005) Fertile peraluminous granites and related rare-element pegmatite mineralization, Superior Province of Ontario. In: R.L. Linnen \& I.M. Samson (Eds.), "rareelement geochemistry and mineral deposits". Geol Assoc Canada Short Course Notes 17:87-125

Brown CD, Wise MA (2001) Internal zonation and chemical evolution of the Black Mountain granitic pegmatite, Maine. Can Mineral 39:4555 
Cathelineau M (1988) Cation site occupancy in chlorites and illites as a function of temperature. Clay Miner 23:471-485

Cathelineau M, Nieva D (1985) A chlorite solid solution geothermometer. The los Azufres (Mexico) geothermal system. Contrib Mineral Petrol 91:235-244

Černý P (1989) Characteristics of pegmatite deposits of tantalum. In: Möller P, Černý P, Saupe F (eds) Lanthanides tantalum and niobium. Springer Verlag, Heidelberg, pp 195-235

Černý P (1991a) Rare-element granitic pegmatites. I Anatomy and internal evolution of pegmatite deposits. Geosci Canada 18(2):49-67

Černý P (1991b) Rare-element granitic pegmatites. II Regional to global environments and petrogenesis Geosci Canada 18(2):68-81

Černý P (1992) Geochemical and petrogenetic features of mineralization in rare-element granitic pegmatites in the light of current research. Appl Geochem 7:393-416

Černý P (1998) Magmatic vs. metamorphic derivation of rare-element granitic pegmatites. Kristallinikum 24:7-36

Černý P, Hawthorne FC (1982) Selected peraluminous minerals. Mineral Assoc Canada Short Course Handbook 8:163-186

Černý P, Ercit TP (2005) Classification of granitic pegmatites revisited. Can Mineral 43:2005-2026

Černý P, Goad BE, Hawthorne FC, Chapman R (1986) Fractionation trends of the $\mathrm{Nb}$ - and Ta-bearing oxide minerals in the Greer Lake pegmatitic granite and its pegmatite aureole, southeastern Manitoba. Am Mineral 71:501-517

Černý P, Ercit TS, Wise MA (1992) The tantalite-tapiolite gap: natural assemblages versus experimental data. Can Mineral 30:587-596

Černý P, Chapman R, Ferreira K, Smeds S-A (2004) Geochemistry of oxide minerals of $\mathrm{Nb}, \mathrm{Ta}, \mathrm{Sn}$ and $\mathrm{Sb}$ in the Varuträsk granitic pegmatite, swede: the case of an "anomalous" columbite tantalite trend. Am Mineral 89:505-518

Černý P, Blevin PL, Cuney M, London D (2005) Granite-Related Ore Deposits. Econ Geol $100^{\text {th }}$ Anniversary Volume, 337-370

Chudík P, Uher P, Gadas P, Skoda R, Prsek J (2011) Niobium-tantalum oxide minerals in the Jezuitské Lesy granitic pegmatite, Bratislava massif, Slovakia: $\mathrm{Ta}$ to $\mathrm{Nb}$ and $\mathrm{Fe}$ to $\mathrm{Mn}$ evolutionary trends in a narrow Be, Cs-rich and Li, B-poor dike. Mineral Petrol 102:15-27

Coira B, Toselli A, Koukharsky M, Rossi de Toselli J, Kay SM (1999) Magmatismo famatiniano. In:" González Bonorino, G., Omarini, R. Y Viramonte, J. (Eds.) Geologia del noroeste Argentino, $14^{\circ}$ Congreso Geológico Argentino, Relatorio 1, 189-211, Salta

Deer WA, Howie RA, Zussman J (1983) An introduction to the rock forming minerals. Longman, New York, p 528

Dill HG (2015) The Hagendorf-Pleystein Province: the center of pegmatites in an ensialic orogeny. Springer International Publishing Switzerland, pp. 474

Eagle RM, Birch WD, McKnight S (2015) Phosphate minerals in granitic pegmatites from the mount wills district, North-Eastern Victoria. Royal Society of Victoria 127:55-68

Elkins LT, Grove TL (1990) Ternary feldspar experiments and thermodynamic models. Am Mineral 75:544-559

Ercit TS (2005) REE-enriched pegmatites. In: R.L. Linnen \& I.M. Samson (Eds.), Rare-Element Geochemistry and Mineral Deposits, Geol Assoc Canada Short Course Notes 17:175-199

Feng Y, Liang T, Yang X, Zhang Z, Wang Y (2019) Chemical evolution of $\mathrm{Nb}$ - $\mathrm{Ta}$ oxides and Cassiterite in phosphorus-rich AlbiteSpodumene Pegmatites in the Kangxiwa-Dahongliutan pegmatite field, Western Kunlun Orogen, China. Minerals 9:166

Fuchsloch WC, Nex PAM, Kinnaird JA (2019) The geochemical evolution of $\mathrm{Nb}-\mathrm{Ta}-\mathrm{Sn}$ oxides from pegmatites of the cape cross-Uis pegmatite belt, Namibia. Mineral Mag 83:161-179

Fuhrman ML, Lindsley DH (1988) Ternary-feldspar modelling and thermometry. Am Mineral 73:201-215

Fulignati P (2020) Clay minerals in hydrothermal systems. Minerals 10: 919
Galliski MA (1981) Estructura, Mineralogía y Génesis de las Pegmatitas de El Quemado, Salta, República Argentina. PhD thesis. Facultad de Ciencias Exactas y Naturales. Universidad Nacional de Córdoba, $143 \mathrm{pp}$

Galliski MA (1983a) Distrito minero El Quemado, departamento La Poma y Cachi, provincia de Salta; I, el basamento del tramo septentrional de la sierra de Cachi. Rev Asoc Geol Argentina 38:209-224

Galliski MA (1983b) Distrito minero El Quemado, departamentos La Poma y Cachi, Provincia de Salta. II: Geología de sus pegmatitas. Rev Asoc Geol Argentina 38:340-380

Galliski MA (1999) Distrito pegmatítico Conlara, San Luis. In: Recursos Minerales de la República Argentina (E.O. Zappettini, ed.). Instituto de Geología y Recursos Minerales SEGEMAR 35:365-368

Galliski MA (2007) Geoquímica de las Formaciones Puncoviscana y Cachi, Sierra de Cachi, Salta. Discusión. Rev Asoc Geol Argentina 62:475-477

Galliski MA (2009) The Pampean Pegmatite Province, Argentina: a review. Estudios Geologicos 19:30-34

Galliski MA, Upton IL (1992) Composición y propiedades de minerales de niobio y tantalio de las pegmatitas graníticas de El Quemado, Provincia de Salta. Rev Asoc Geol Argentina 47:323-331

Galliski MA, Černý P (2006) Geochemistry and structural state of columbite-group minerals from granitic pegmatites of the Pampean ranges. Can Mineral 44:645-666

Galliski MA, Marquez-Zavalía MF, Pagano DS (2019) Metallogenesis of the Totoral LCT rare-element pegmatite district, San Luis, Argentina: a review. J S Am Earth Sci 90:423-439

Galliski MA, Saavedra J, Marquez-Zavalía MF (1999) Mineralogía y geoquímica de las micas en las pegmatitas Santa Elena y el Peñón, Provincia Pegmatítica Pampeana, Argentina. Rev Geol Chile 26:125-137

Galliski MA, Toselli A, Saavedra J (1990) Petrology and geochemistry of the Cachi high-alumina trondhjemites, northwestern Argentina. In: Kay S and Rapela C (Eds) Plutonism from Cachi 81 Antarctica to Alaska. Geol Soc Am Special Paper 241:91-100

Gonçalves AO, Melgarejo JC, Alfonso P, Paniagua A (2008) Composición de la Turmalina de las Pegmatitas Graníticas de Giraúl, Angola. Rev Soc Espan Mineral 9:125-126

Harbi HM, Surour AA, Davidson GJ (2014) Genesis of Neoproterozoic Au-bearing volcanogenic sulfides and quartz veins in the Ar Rjum goldfield, Saudi Arabia. Ore Geol Rev 58:110-125

Heimann A, Yonts JA, Galliski MA (2015) The composition of gahnite in granitic pegmatites from the Pampean Pegmatite Province, Argentina: implications for pegmatite fractionation. Can Mineral 53:1-26

Henry DJ, Guidotti CV (1985) Tourmaline as a petrogenetic indicator mineral: an example from the staurolite-grade metapelites of NW Maine. Am Mineral 70:1-15

Henry DJ, Novàk M, Hawthorne FC, Ertl A, Dutrow BL, Uher P, Pezzotta F (2011) Nomenclature of the tourmaline-supergroup minerals. Am Mineral 96:895-913

Hongn FN, Seggiaro RE (2001) Hoja Geológica Cachi, 2566-III, Provincias de Salta y Cata-marca, República Argentina, Inst. Geol. y Rec. Mineral., Serv. Geol. Minero Argent., Buenos Aires 248, 87 pp.

Hongn FN, Tubia JM, Esteban JJ, Aranguren A, Vegas N, Sergeev S, Larionov A, Basei M (2014) The sierra de Cachi (Salta, NW Argentina): geological evidence about a Famatinian retro-arc at mid crustal levels. J Iber Geol 40:225-240

Jahns RH, Burnham CW (1969) Experimental studies of pegmatite genesis: I. a model for the derivation and crystallization of granitic pegmatites. Econ Geol 64:843-864

Kontak DJ (2006) Nature and origin of a LCT suite pegmatite with latestage sodium enrichment, Brazil Lake, Yarmouth County, Nova Scotia. I. Geological setting and petrology. Can Mineral 44:563-598 
Kranidiotis P, MacLean WH (1987) Systematics of chlorite alteration at the Phelps dodge massive sulfide deposit, Matagami, Quebec. Econ Geol 82:1898-1911

Linnen RL (2004) Ferrocolumbite-manganotantalite trends in granites and pegmatites: experimental and natural constraints. Geol Soc Am Prog Abstract 36

Linnen RL, Keppler H (1997) Columbite solubility in granitic melts: consequences for the enrichment and fractionation of $\mathrm{Nb}$ and ta in the Earth's crust. Contrib Mineral Petrol 128:213-227

Linnen RL, Cuney M (2005) Granite-related rare-element deposits and experimental constraints on $\mathrm{Ta}-\mathrm{Nb}-\mathrm{W}-\mathrm{Sn}-\mathrm{Zr}-\mathrm{Hf}$ mineralization. In: Linnen R and Samson I M (Eds) rare- element geochemistry and mineral deposits. Geol Assoc Canada Short Course Notes 17:45-68

London D (1992) The application of experimental petrology to the genesis and crystallization of granitic pegmatites. Can Mineral 30:499 540

London D (2005) Granitic pegmatites: an assessment of current concepts and directions for the future. Lithos 80:281-303

London D, Hunt LEH, Schwing CR, Guttery BM (2020) Feldspar thermometry in pegmatites: truth and consequences. Contrib Mineral Petrol 175:8

Lucassen F, Fowler CMR, Franz G (1996) Formation of magmatic crust at the Andean continental margin during early Mesozoic: a geological and thermal model of the north Chilean coast range. Tectonophysics 262:263-279

Mamadou MM, Cathelineau M, Bourdelle F, Boiron M-C, Elmaleh A, Brouand M (2016) Hot fluid flows around a major fault identified by paleothermometric studies (Tim Mersoi Basin, Niger). J Sediment Res 86:914-928

Marks MAW, Marschall HR, Schuhle P, Guth A, Wenzel T, Jacob DE, Barth M, Markl G (2013) Trace element systematics of tourmaline in pegmatitic and hydrothermal systems from the Variscan Schwarzwald (Germany): the importance of major element composition, sector zoning, and fluid or melt composition. Chem Geol 344: 73-90

Márquez-Zavalía MF, Galliski MA, Černý P, Chapman R (2012) An assemblage of bismuth-rich, tellurium minerals in the El Quemado granitic pegmatite, Nevados de Palermo, Salta, Argentina. Can Mineral 50:1489-1498

Martinez-Serrano RG, Dubois M (1998) Chemical variations in chlorite at the Los Humeros geothermal system, Mexico. Clay Clay Miner 46:615-628

Miller H, Lork A, Toselli AJ, Acenolaza FG (2019) Geoquímica y geocronología de las rocas ígneas de la Formación Cachi, en el Valle Calchaqui, Argentina. Serie Correl Geol 35:41-75

Monier G, Robert JL (1986) Evolution of the miscibility gap between muscovite and biotite solid solutions with increasing lithium content: an experimental study in the system $\mathrm{K}_{2} \mathrm{O}-\mathrm{Li}_{2} \mathrm{O}-\mathrm{MgO}-\mathrm{FeO}-$ $\mathrm{Al}_{2} \mathrm{O}_{3}-\mathrm{SiO}_{2}-\mathrm{H}_{2} \mathrm{O}-\mathrm{HF}$ at $600 \sim 2 \mathrm{kbar} \mathrm{P}_{\mathrm{H} 2 \mathrm{O}}$ : comparison with natural lithium micas. Mineral Mag 50:641-651

Nabelek PI, Russ-Nabelek C, Denison JR (1992) The generation and crystallization conditions of the Proterozoic Harney peak Leucogranite, Black Hills, South Dakota, USA: petrologic and geochemical constraints. Contrib Mineral Petrol 110:173-191

Novàk M, Černý P, Uher P (2003) Extreme variation and apparent reversal of $\mathrm{Nb}$-Ta fractionation in columbite-group minerals from the Scheibengraben beryl-columbite granitic pegmatite, Maršíkov, Czech Republic. Eur J Mineral 15:565-574

Orberger B, Rojas W, Millot R, Flehoc C (2015) Stable isotopes (Li, O, $\mathrm{H})$ combined with brine chemistry: powerful tracers for Li origins in Salar deposits from the Puna region, Argentina. Proc Earth Planet Sci 13:307-311

Palacio AH, Devito HA (1947) Las pegmatitas portadoras de minerales de Bismuto, Columbio y Tantalio de la zona de El Quemado, provincia de Salta. Dirección General de Fabricaciones Militares, Informe 47,4: 112-125. Buenos Aires
Pant S, Singh S, Sahoo PR, Kumar A, Saravanan B, Venkatesh AS, Yadav GS, Kumar P (2019) Mineral chemistry and geothermometry of chlorites in relation to physicochemical conditions of uranium mineralization in the central part of the Singhbhum shear zone, eastern India. Ore Geol Rev 112:102997

Putirka KD (2008) Thermometers and barometers for volcanic systems. Rev Mineral Geochem 69:61-120

Raimbault L (1998) Compositions of complex lepidolite-type pegmatites and of constituent columbite-tantalite, Chédeville, massif central, France. Can Mineral 36:563-583

Ramos VA (2017) Las provincias geológicas del noroeste argentino. In: Muruaga CM, Grosse P (eds) Ciencias de la Tierra y Recursos Naturales del NOA, Relatorio XX Congr. Geol. Arg, San Miguel de Tucumán, pp 42-56

Raza MQ, Absar N (2021) Mineral chemistry of hydrothermal alteration assemblage in hanging wall Shahapur granite associated with veintype Gogi uranium deposit, Bhima Basin, eastern Dharwar Craton, India: implications for physico-chemical conditions of ore formation. Ore Geol Rev 128:103880

Rieder M, Cavazzini G, D'yakonov YS, Frank-Kamenetskii VA, Gottardi G, Guggenheim S, Koval PV, Müller G, Neiva AMR, Radoslovich EW, Robert JL, Sassi FP, Takeda H, Weiss Z, Wones DR (1998) Nomenclature of the micas. Mineral Mag 63(2):267-279

Rossi de Toselli J, Toselli A, Willner A, Medina ME (1987) Geotermobarometría de granate-biotita-cordierita en los gneises de alto grado entre las regiones de Cafayate y Colalao del Valle, Sierra de Quilmes. Actas $10^{\circ}$ Congr. Geol. Arg. Tucumán 3:25-30

Sardi FG, De Barrio R, Colombo F, Marangone S, Ramis A, Curci M (2017) Pegmatitas graniticas de la region noroeste de Argentina. Proceedings XX Congreso Geologico Argentino, Tucuman 2017: 971-1002

Simmons WB, Webber KL (2008) Pegmatite genesis: state of the art. Eur J Mineral 20:421-438

Sirbescu M-L, Nabelek P (2003) Crystallization conditions and evolution of magmatic fluids in the Harney peak granites and associated pegmatites, Black Hills, South Dakota - evidence from fluid inclusions. Geochim Cosmochim Acta 67:2443-2465

Soares DR, Beurlen H, Ferreira ACM, Da-Silva MRR (2007) Chemical composition of gahnite and degree of pegmatitic fractionation in the Borborema Pegmatitic Province, northeastern Brazil. Anais da Academia Brasileira de Ciencias 79:395-404

Tindle AG, Breaks FW (2000) Columbite-tantalite mineral chemistry from rare-element granitic pegmatites: separation Lake area, N.W. Ontario, Canada. Mineral Petrol 70:165-198

Tindle AG, Breaks FW, Selway JB (2002) Tourmaline in petalite-subtype granitic pegmatites: evidence of fractionation and contamination from the Pakegama lake and separation lake areas of northwestern Ontario, Canada. Can Mineral 40:753-788

Tischendorf G, Gottesmann B, Forster H-J, Trumbull RB (1997) On Libearing micas: estimating $\mathrm{Li}$ from electron microprobe analyses and an improved diagram for graphical representation. Mineral Mag 61: 809-834

Tischendorf G, Rieder M, Forster H-J, Gottesmann B, Guidotti CV (2004) A new graphical presentation and subdivision of potassium micas. Mineral Mag 68:649-667

Toselli A (1992) El magmatismo del noroeste argentino. Reseña sistemática e interpretación. Universidad Nacional de Tucumán. Serie Correl. Geol. 8, 243 p. Tucumán

Trumbull RB, Chaussidon M (1999) Chemical and boron isotopic composition of magmatic and hydrothermal tourmalines from the Sinceni granite-pegmatite system in Swaziland. Chem Geol 153: $125-137$

Trumbull RB, Garda GM, Xavier RP, Cavalcanti JAD, Codeco MS (2009) Tourmaline in the Passagem de Mariana gold deposit (Brazil) revisited: major-element, trace-element and B-isotope constraints on metallogenesis. Mineral Deposita 54:395-414 
Van Hinsberg VJ, Henry DJ, Marschall HR (2011) Tourmaline: an ideal indicator of its host environment. Can Mineral 49:1-16

Van Lichtervelde MV, Beziat SSD, Linnen RL (2007) Textural features and chemical evolution in tantalum oxides: magmatic versus hydrothermal origins for ta mineralization in the Tanco lower pegmatite, Manitoba, Canada. Econ Geol 102:257-276

Whitney DL, Evans BW (2010) Abbreviations for names of rock-forming minerals. Am Mineral 95:185-187

Vasquez M, Nieto F, Morata D, Droguett B, Carrillo-Rosua FJ, Morales S (2014) Evolution of clay mineral assemblages in the Tinguiririca geothermal field, Andean cordillera of Central Chile: an XRD and HRTEM-AEM study. J Volcanol Geotherm Res 282:43-59

Wang N (1994) The cu-bi-S system: results from low temperature experiments. Mineral Mag 58:201-204
Wise MA, Francis CA, Černý P (2012) Compositional and structural variations in columbite-group minerals from granitic pegmatites of the Brunswick and Oxford fields, Maine: differential trends in Fpoor and F-rich environments. Can Mineral 50:1515-1530

Zhou Q, Li W, Wang G, Liu Z, Lai Y, Huang J, Yan G, Zhang Q (2019) Chemical and boron isotopic composition of tourmaline from the Conadong leucogranite-pegmatite system in South Tibet. Lithos 326-327:529-539

Publisher's note Springer Nature remains neutral with regard to jurisdictional claims in published maps and institutional affiliations. 